支部・集談会記事

\section{日本臨床外科学会北海道支部抄録 (第109回北海道支部総会)}

\author{
日 時：平成28年 7 月 2 日（土） $9: 25 \sim$ \\ 会＼cjkstart場：北海道立道民活動センターかでる 2.7 \\ 支部長 : 平田 公一 \\ 会 長：樫村 暢一
}

術関連死亡は誤興による 1 例のみであり, 術後在院期間の中央値 は13日（6８6日）であった。病理stage分布はIB/IIA/IIB/ IIIA/IIIB/IIICの順に109例（36.3\%）/77例（25.7\%）/48例（16.0 \%）/31例（10.3\%）/19例（6.3\%）/16例（5.3\%）であった．再 発は62例 $(20.7 \%)$ に認め, 再発部位として腹膜29例，リンパ節 16例，肝14例の順に多かった。 5 年生存率は relapse free survivalでは, $88.0 \% / 81.6 \% / 57.2 \% / 48.8 \% / 47.4 \% / 35.0 \%$ でり, overall survivalでは89.9\% /82.2\% /61.3\% /63.5\% /45.1\% /50.0\% であった，再発因子の検討においては, 多変量解析の結果, 病理 stageのほかにC-D grade III 以上の合併症を有した症例で有意 に予後不良であった.【まとめ】本年 1 月に発表された全がん協 の報告では, 2004 2007年までの胃癌手術症例 stage 別 5 年相対 生存率はI/II/IIIの順に $96.0 \% / 66.9 \% / 48.1 \%$ ありり, 当科関連施 設における進行癌に対するLGの中長期成績は遜色ない結果と思 われた。 また， C-D grade III以上の合併症は再発リスクとなる 可能性が示唆された．今後は前向き観察研究などを行うことによ って, 進行胃癌に対する適応拡大の妥当性を示すことが課題と考 える.

II 肝細胞癌における顕微鏡的門脈侵襲の予測因子と系統 的肝切除の意義 北海道大学大学院消化器外科学分野 I

島田慎吾、神山俊哉、横尾英樹、折茂達也、若山顕治、永生高 広、蒲池浩文、武富紹信

【背景】肉眼的門脈侵襲を伴う肝細胞癌（HCC）は非常に予後不 良であり、顕微鏡的門脈侵襲（vp 1）も予後不良因子であるが、 術前に予測しうるのは困難である。一方、系統的肝切除術の優位 性は報告されているが、vp 1 を伴う HCCに対する意義は十分検 討されていない。

【方法】1990年から2014年 5 月までのR０もしくはR１切除を施 行したHCC切除例852例を対象とした。vp 1 に対する初回肝切除 例vp 1 -HCC群153例と門脈侵襲のないvp 0-HCC群699例にお いて患者因子、腫瘍因子、病理学的因子を比較し、vp 1 を予測 する因子を検討した。vp 1-HCC 群の予後、再発因子については 単独で単変量、多変量解析を行い解析した。さらに系統的肝切除 (ALR) の予後への影響について背景因子を均一化した傾向スコ ア解析 Inverse Probability of Treatment Weighted (IPTW) 法 を用いて非系統的切除 (NALR) と比較検討した。

【結果】（1）vp 1-HCC 群と vp 0-HCC 群の比較 : 多変量解析に て HBs-Ag陽性（HR 1.7275、95\% CI 1.0569-2.8236、p=0.02）、 PIVKA-II $\geq 100 \mathrm{mAU} / \mathrm{ml}$ (HR 2.8860、95\% CI 1.8709-4.4520、p $<0.01$ )、腫瘍径 $\geq 5 \mathrm{~cm}$ (HR 1.5534、95\% CI 1.0057-2.3994、 $\mathrm{p}=0.04$ ）、多結節癒合型（HR 1.8429、95\% CI 1.1461-2.9633、 $\mathrm{p}=0.01$ ）、低分化（HR1.5214、95\% CI 1.0104-2.2909、 $\mathrm{p}=0.04 ）$ が vp 1 の予測因子であった。

（2）vp 1-HCC群における予後：5 年生存率 $47 \%$ 、平均生存期 間57ヶ月 (中央値) であった。多変量解析における生存には血小 板 $<100,000 / \mathrm{mm} 3$ 、PIVKA-II $\geq 100 \mathrm{mAU} / \mathrm{ml}$ 、多発、腫瘍径 $\geq$ $5 \mathrm{~cm}$ 、切除断端陽性が、再発にはPIVKA-II $\geq 100 \mathrm{mAU} / \mathrm{ml}$ 、多発、 腫瘍径 $\geq 5 \mathrm{~cm}$ 、切除断端陽性が有意な子後不良因子であった。

（3）vp 1-HCC群におけるALRの意義：ALR（n=121）、NALR $(\mathrm{n}=32)$ 。腫瘍径 $\geq 5 \mathrm{~cm}$ の症例がALR 63\%、NALR 19\%（p< 0.01）と背景因子に有意な違いを認めた。そのためIPTW 法を用 い背景因子を調整すると、ALRは生存；HR0.3718、95\% CI 0.2464-0.5609、p $<0.01$ 、再 発; HR 0.1601、95 \% CI 0.08790.2917、 $\mathrm{p}<0.01$ と予後良好因子として抽出された。 
【結語】PIVKA-II高値、腫瘍径 $5 \mathrm{~cm}$ 以上、多結節癒合型、 $\mathrm{HBs}^{-}$ $\mathrm{Ag}$ 陽性といった特徵を有する HCC 症例に対しては画像評価で門 脈腫瘍栓を認めない場合であっても顕微鏡的門脈侵襲を伴う可能 性が高く、系統的肝切除術の必要性が高いと考えられた。

\section{III 待機的結腸癌切除症例に対するERAS導入の安全性 と有効性の検討 \\ 手稲渓仁会病院外科}

○寺村紘一、中村文隆、篠原良仁、伊橋卓文、横山新一郎、水沼 謙一、吉見泰典、武内慎太郎、今村清隆、早馬 聡、田本英司、 高田 実、木ノ下義宏、安保義恭、樫村暢一

【背景と目的】ERAS (Enhanced Recovery After Surgery) と は術後患者の生理的機能を維持し、手術後の早期回復を目指した 周術期管理プロトコールであり、早期栄養開始などのエビデンス のある方法を集学的に実施することで、安全性の向上（術後合併 症減少), 在院期間短縮掞よび医療資源やコストの削減を実現す ることができる。2005年に欧州の静脈経腸栄養学会を中心とした グループが提唱し、近年普及しはじめているものの、本邦におけ るERASの成績についての報告は少ない。そこで、今回待機的結 腸癌切除症例に対するERAS 導入の安全性と有効性を検討した。 【対象と方法】結腸癌（結腸及び直腸 S 状部）の待機手術患者550 例を対象とし、2011年 9 月から2015年 8 月までの ERAS群（以下 E群） 372 例と2010年 1 月から 2011 年 9 月までERAS導入以前の 従来管理群 (以下 C 群) 178 例の 2 郡に分け、術後合併症、術後 在院期間、再入院率および医療費を後方視的に比較検討した。（当 院ERAS プロトコール概要）術前の十分なカウンセリング、術前 絶飲食の廃止、手術当日の炭水化物飲料の摂取、術中の制限輸液 管理、腹腔鏡下手術の推奨、不必要なドレーン㨂入の回避、硬膜 外麻酔、アセトアミノフェン、NSAIDsによる多角的疼痛対策、 リスク因子に基づく術後の悪心・嘔吐対策、術後 1 日目からの早 期栄養摂取、早期離床などから成り、退院可能日は術後 5 日目に 設定した。

【結果】 $(\mathrm{E}$ 群/C 群) 患者背景では、平均年齢 $(71 / 72$ 歳)、男:女 比 (203:169/100:78例), ASA (ASA physical status) 分類 $1: 2$ : 3 （71:273:28/35:124:19例）は同等であったが、腹腔鏡手術率は、 E 群 $98.3 \% ， C$ 群 $83.7 \% （ \mathrm{p}<0.01 ）$ と 群で高率であった。なお、 E群のERASプロトコール達成率（食事遅延無し）は91.9\% (343/372) であった。

（1）術後合併症 (C-D 分類 Grade III 以上）は、E群4.3\% (16例)、 C群 $7.8 \%$ （14例）（ $\mathrm{p}=0.08 ）$ と有意な違いは認められなかった。 また、合併症のうち縫合不全は E 群 6 例 (1.6\%)、C 群 3 例 (1.7\%)) と同程度であった。

（2）術後在院期間（中央值）は、E群: 5 日， C群: 8 日（p $<$ 0.01）と E 群で 3 日間の有意な短縮を認めた。また、ASA別の術 後在院期間 (平均值) では、ASA 1 分類 (6.2/9.5日)、ASA 2 分 類 $(7.2 / 10.7$ 日)、ASA 3 分類 $(9.1 / 15.9$ 日 $)(\mathrm{p}<0.01)$ であり、 ASA 不良群ほどE 群と C 群の在院期間短縮の効果は大きいこと が認められた。

（3）再入院率（術後30日以内）は、E群 $3.2 \%$ (12例), C群3.4 \%（6 例）と同等であった。再入院の内訳は、E群（腸閉塞 5 , 腹腔内膿瘍 3 , 縫合不全 1 , 腸炎 1 , 脳梗塞 1 、転倒による硬膜 下血腫 1 )、C 群（腸閉塞 3 , 胃潰瘍出血 1 、不整脈 1 、虚血性 心疾患 1 ) であった。

（4） DPC算定総医療費は、E群 $¥ 1,364,731 ， C$ 群 $¥ 1,531,413$ （p <0.01）と、E群で16万円ほど有意に減少していた。出来高算定 での医療費の内訳をみると、入院基本料（¥214,681/ ¥353,596），
投薬料（ $¥ 4,137 / ¥ 10,612 ） 、$ 注射代（ $¥ 10,421 / ¥ 41,702 ）$ いず れも E群で有意に減少していた。

【結語】ERAS群において、術後合併症率および再入院率の増加 はなく、ERAS導入の安全性が認められた。またERAS群におい て、術後在院期間㧍よび総医療費は有意に減少しており、早期回 復と医療資源と医療費の削減を実現するERASの有効性が示さ れた。

\section{一般演題}

1 長期生存した食道胃接合部内分泌細胞癌の 1 例

$\mathrm{JA}$ 北海道厚生連帯広厚生病院外科

丹羽弘貴、村川力彦、山本博之、加藤航平、武藤 潤、山村喜之、 市之川正臣、大竹節之、大野耕一

症例は64歳男性, 食後のつかえ感と体重減少で当院を受診. 上部 消化管造影では下部食道から噴門にかけての大きな潰瘍性病変, 上部消化管内視鏡で食道胃接合部に 3 型腫瘍を認めた。生検では 低分化の癌種と診断された. CTでは下部食道から噴門にかけて 全周性の壁肥厚と胃小弯のリンパ節腫大を認めたが遠隔転移を認 めなかった. 以上より食道胃接合部癌の診断で左開胸開腹下部食 道胃全摘術を施行した。病理学的所見では大型の異型類円形核を 有する癌細胞が柵状構造をもって増殖. 免疫染色ではクロモグラ ニンA， CD56陰性，シナプトフィジンは陽性となった。核分裂 像は40/10HPF, MIB-1 index 50\%であり, 大細胞型内分泌細 胞癌と診断した. UE, type2,8x6.5cm, pT 3 (SS), ly 0, v 2 , $\mathrm{pN} 1$, Stage II B と診断した. 術後補助化学療法として $\mathrm{S}-1$ 投 与を 1 年間行い, 4 年 8 ケ月の無再発生存している.

\section{2 術前に診断しえた食道神経内分泌癌の 1 切除例} 札幌医科大学医学部医学科6年1、北海道社会事業協会余市病院外 科 ${ }^{2}$

福田摩莉佳 1,2 、那須裕也 2 、横山和之 2 、吉田秀明 2

症例は77歳男性. 低体温で倒れているところを発見され当院へ救 急搬送された. 来院時意識は清明であったが $\mathrm{Hb} 4.6$ と高度の貧血 を認めた。上部消化管内視鏡検查で胃潰瘍と下部食道胃接合部に 腫瘤を認め, 腫瘤からは生検で低分化型の carcinomaで, chromograninA 陽性, synaptophysin 陽性であることから食道神経内 分泌癌と診断した. 全身精査では\# 7 , \#11pに腫大したリンパ 節を認め転移が疑われたが, 遠隔臓器への転移が確認されず手術 の方針とした。手術は年齢や侵襲を考え，胃全摘出術を選択. リ ンパ節は術前の画像診断どおりに\# 7, \#11pに転移を認めたが, 周囲との癒着もなかった. 合併症は認めず術後21日目で退院した. 食道神経内分泌癌は術前診断率が $24 \%$ と低值であり, また血行転 移をしやすいことから予後は不良とされている。 また手術単独で は 1 年生存率が $33 \%$ と報告されており, 集学的治療が必要と考え られる. 術前に診断しえた貴重な食道神経内分泌癌の 1 切除例を 報告する.

\section{3 難治性良性食道狭窄の 1 例 市立札幌病院外科}

沢田克史、大島隆宏、有村聡士、大島由佳、齊藤健太郎、上坂貴 洋、寺崎康展、皆川のぞみ、奥田耕司、大川由美、三澤一仁 症例は、52歳男性。前医にて46歳頃から逆流性食道炎の診断で内 服加療を受けていたが、2013年 4 月頃から胸部下部食道に狭窄を 認め、2013年10月食道バルーン拡張術施行するも再狭窄を来し 3 〜 5 カ月毎に食道バルーン拡張術を繰り返していた。転居に伴い、 
2015年12月に当院消化器内科紹介受診し、2016年 1 月食道バルー ン拡張術施行するも術後早期に再狭窄を認め、飲水も困難な状況 となったことから、手術目的に当科紹介。複数回施行された生検 では悪性所見や感染所見は認めなかった。2016年 3 月食道狭窄部 切除、胸䏶内食道全胃吻合術を施行。術後経過良好にて術後38日 目に退院となった。病理組織学的検査で食道表層にびらん、潰瘍 を認め、間質にリンパ球と形質細胞の浸潤を認めた。食道壁は線 維化を伴って高度に肥厚しており、慢性炎症による食道狭窄とし て矛盾しない所見であった。また免疫組織学的に IgG 4 陽性形質 細胞を多数認めた。切除を要した難治性良性食道狭窄の 1 例を経 験したので、若干の文献的考察を加えて報告する。

\section{4 胸腔鏡を用い、下部食道の切離と再建を施行した食道 胃接合部癌の 1 例 \\ 函館中央病院外科}

橋田秀明、児嶋哲文、平口悦郎、松村祥幸、芦立嘉智、和田雅孝、 木村弘太郎

症例は、60歳、男性. 平成 28 年 2 月、吐血で当院入院となった. 上部消化管内視鏡では、門歯より $38 \mathrm{~cm}$ 、下部食道から噴門に達 する $3 / 4$ 周性の 2 型腫瘍を認め、生検では pap tub 1-2であ った. 上部消化管造影では、食道浸潤長 $5 \mathrm{~cm}$ 、腫瘍の中心は食 道胃接合部口側 $1.5 \mathrm{~cm}$ であり、食道胃接合部癌 $(\mathrm{E}>\mathrm{G}$ 、Giewert type 1）と診断した. CTでは、右肺S 6 に $6 \mathrm{~mm}$ 大の結節影が あり転移が疑われたが、入院後、つかえ感の訴えがあり、下部食 道切除、噴門側胃切除の方針とした. 手術は分離肺換気下、右半 側臥位で行った。腹腔鏡操作を先行し、 5 ポートで胃切離、経裂 孔的に食道周囲の剥離を行った.つづいて、胸腔鏡下に 4 portで、 左下肺静脈下縁まで食道周囲を剥離した，術中エコーで腫瘍の口 側を確認し、自動䋮合器で下部食道を切離した. 第 1 ・第 2 空腸 動脈を切離し、結腸後経路で空腸を挙上し、OrVilTMを使用し 食道空腸吻合を施行した. 腹部の再建はダブルトラクト法で行っ た。術後、人工呼吸器管理を要したが、術後 3 日目に離脱した。 術後 6 日目の消化管造影では食道空腸吻合部の leakageを認め ず、術後 7 日目 胃管抜去、術後 8 日目より経口攝取を再開し、 術後20日目に退院となった。病理では $\mathrm{pN} 3 \mathrm{a} 、 \mathrm{pPM} 15 \mathrm{~mm}$ であ った. 胸腔鏡を用いることで、下部食道の切離と、再建（食道空 腸吻合）を安全で低侵襲に行えたと考えられる。

\section{5 粘膜下腫瘍様の形態を示した胃癌の 1 例} 恵佑会札幌病院消化器外科 1 、同病理診断科 ${ }^{2}$

坂下啓太 ${ }^{1} 、$ 西田靖仙 1 、上村志臣、大場光信 1 、澄川宗祐 1 、碓井

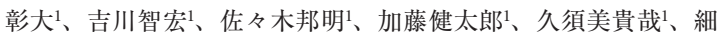
川正夫 1 、大内知之 ${ }^{2}$ 、武内利直 ${ }^{2}$

症例は70歳代、男性。2010年の上部消化管内視鏡検查にて胃穹蕯 部大弯前壁に中心部に粘液の付着のある胃粘膜下腫瘍様隆起を認 め、EUSでは第3層に存在し、液体貯留部をもち炎症性変化がめ だっていた。生検はGroup1であり、経過観察の方針とした。 2015年4月までは大きさ、形態の変化を認めなかった。10月に貧 血認め施行した内視鏡検査にて、粘膜下腫瘍様隆起の頂部に潰瘍 を認め、生検はGroup5,腺癌であり、cT2N0M0の診断で、噴門 側胃切除術を施行した。病理組織診断では粘膜内の中〜低分化腺 癌と、連続して媣部側方に高度に進展する乳頭状腺癌を認めた。 深部では異型のそしい粘膜下異所性胃腺と、腺癌成分との移行像 が認められた。pT2pN0であった。臨床経過からは炎症、異所性 胃腺により囊胞状、粘膜下腫瘍様の形態で経過観察していた病変 内で癌化し、頂部が決壊する形で潰瘍性病変を形成したと推察さ
れる。胃粘膜下腫瘍様の形態を示す胃癌は比較的まれであり、異 所性胃腺との関連が疑われる症例は少ない。形態的変化を観察し えた症例を経験したため報告する。

6 十二指腸下行脚に発症した低悪性度腫瘍に対して LECSを施行した 2 例

札棍医科大学消化器 - 総合、乳腺 - 内分泌外科 1 、市立室蘭総合 病院外科 2

渡久山晃 ${ }^{1,2}$ 、伊東竜哉1、信岡隆幸1、秋月恵美1、植木知身 1 、西舘 敏彦1、沖田憲司1、佐々木賢一2、古畑智久 1 、竹政伊知朗 ${ }^{2}$

【はじめに】十二指腸低悪性度腫瘍は、Vater乳頭温存と十二指 腸の変形・狭窄防止から可及的小範囲切除が求められ、腹腔鏡 · 内視鏡合同下手術 (LECS) の良い適応である。今回我々は、 十二指腸病変に対するLECSを 2 例経験した。【症例 1】十二指 腸下行脚・Vater 乳頭対側の長径 $25 \mathrm{~mm}$ のIIa+IIc 病変（tubular adenoma)。【症例 2】十二指腸下行脚・Vater 乳頭対側の長径 20mmのIIa病変（tubulovillous adenoma）。術式】 5 portで手 術を行う。内視鏡下に腫瘍周囲をマーキングした後、腫瘍口側 1 / 3 周ほどに全層切開を加える。次に腹腔鏡下に腫瘍を含む十二 指腸壁を眽転させ、残り $2 / 3$ 周の全層切開を行い、標本を摘出 する。十二指腸開密部は自動縫合器で縫合閉鎖する。【術後経過】 いずれも合併症無く経過し、それぞれ術後12日、8 日で退院した。 【まとめ十二指腸低悪性度腫瘍に対する手術は、可及的小範囲 切除と確実な縫合閉鎖が重要であるが、その点においてLECSは 有用と思われた。

\section{7 十二指腸球部に脱出した腫瘍を伴った同時多発胃癌の 1 例}

製鉄記念室蘭病院外科・呼吸器外科

箱崎頌平、千葉龍平、パウデルサシーム、佐藤彰記、大高和人、 東海林安人、長谷龍之介、市村龍之助、仙丸直人

胃腫瘍が十二指腸へ脱出した症例は報告されているが、多発胃癌 を伴う症例は稀である。症例は70代男性。両下腿浮腫と食思不振 で当院消化器内科を受診し、CTで胃幽門部の壁肥厚扔よび内䏶 の狭小化を認めた。EGD所見は幽門部が変形し同部位に有茎性 腫瘤を認め十二指腸球部へ脱出していた。また胃角部小弯に0II a 病変を認め、ともに胃癌の診断となった。術中に腫瘍を胃内 へ還納し、幽門側胃切除手術を施行した。基部が胃体下部大弯の 有茎性腫瘍（ $\mathrm{sm} ）$ と胃体中部小弯 0 - II a 病変 $(\mathrm{m})$ を認めた。 さらに術前に指摘されなかった胃体下部後壁 0 - II a 病変 $(\mathrm{m})$ も認めた。腫瘍連続性を認めなかったことから同時多発胃癌と判 断し、pT 1 b,N 0 ,M 0 ,pStageIAの診断となった。経過良好で術 後13日目に退院した。

十二指腸嵌頓を来たした胃癌の場合、胃の変形が著明となること から幽門部付近の観察が不十分になる可能性があるため、切除す る際には十分な注意が必要であると考えられた。 
8 NAC 後の胃全摘+他臟器合併切除により治瘾切除し えた進行胃癌の一例

$\mathrm{JA}$ 北海道厚生連旭川厚生病院外科 ${ }^{1}$ 、同病理診断科 ${ }^{2}$

合地美香子 1 、稲垣光裕 1 、近藤享史 1 、大平将史 1 、山田健司 1 、船 越 徹1 柳田尚之 ${ }^{1}$ 芝木泰一郎 ${ }^{1}$ 池上 淳 ${ }^{1}$ 赤羽弘充 ${ }^{1} 、$ 中野 詩朗1、佐藤啓介 ${ }^{2}$

79歳男性、心窩部不快感・体重減少で当院消化器科受診した。特 記すべき既往歴はなく、触診上腹部は軟で腫瘤は触れなかった。 腫瘍マーカーはCEA195.9ng/ml、CA19- $9185.4 \mathrm{U} / \mathrm{ml}$ と高值で あった。上部消化管内視鏡で胃体部後壁を中心に大きな 3 型腫場 を認め生検で tub 1 -tub 2 の診断となった。CTでは胃体部上部 から穹隆部に壁肥厚あり、膵尾部浸潤、脾浸潤、横隔膜浸潤の可 能性を指摘された。小弯・膵上縁及び脾門部に腫瘤ありリンパ節 転移が疑われた。術前診断として胃癌、UM、Post、Type 3、 tub 1-tub 2、cSI（膵臓、脾臓、横隔膜） N 3、H 0、M 0 cStage III C。術前補助化学療法（NAC）後に手術する方針とな った。S- 1 + CDDP 3 コース施行 ( 1 コース目:S- 1 100mg/日・ CDDP 90mg、2 コース目:S- $180 \mathrm{mg}$ /日・CDDP 90mg、3 コー ス目:S- $180 \mathrm{mg}$ /日・CDDP 90mg)。3 コース目にGrade 1 の嘔気、 倦点感があったもののその他有害事象は認められなかった。 NAC後の評価CTでは胃癌とリンパ節転移の縮小は良好ではあ るが残存ありと評価された。

3 コース終了 22 日後に胃全摘 + 胆囊摘出 + 膵尾部・脾臓・横行結 腸合併切除 (Roux en Y 再建) 施行された。術中所見として腹水 洗浄細胞診陰性・腹膜播種なし・肝転移なく、明らかな非治瘉因 子は認められなかった。膵上縁の腫大リンパ節が横行結腸・膵尾 部に浸潤して一塊となっているため、合併切除となった。病理診 断としてUM、Post,、Type 3、tub 2 -por、pT 4 a (SE)、sci、 INFc、ly $3 、 \mathrm{v} 1 、 \mathrm{pN} 3(7 / 36) 、 \mathrm{pPM} 0 、 \mathrm{pDM} 0 、 \mathrm{cH} 0 、 \mathrm{cP} 0$ 、 CY $0 、$ cM $0 、$ pStage III B で、化学療法の効果判定は grade 2 で あった。術後経過はPOD 6 に膵液漏の合併が認められるも保存 的に改善し、POD46に退院となった。術後補助化学療法として S- 1 （100mg/日）を内服継続中。術後 1 年目のCTでは局所再発、 リンパ節転移、腹膜播種、遠隔転移など腫瘍再発の所見は認めら れなかった。NAC後の外科的切除で治癒しえた進行胃癌の一例 を経験したので、文献的考察を含めて報告する。

9 S-1 + シスプラチン療法後に治癒切除が可能となった Stage IV 胃癌の 1 例

勤医協中央病院外科

石井健一、吉田 信、杤窪 藍、諸星直輝、浅沼和樹、澤崎兵庫、 奈良智志、中村祥子、阿部慎司、田尾嘉浩、林 浩三、川原洋一 郎、後藤 剛、山川智士、鎌田英紀、高梨節二、樫山基矢、石後 岡正弘、河島秀昭、松毛県一

75歳女性. 前医で貧血精查の上部消化管内視鏡で胃体下部前壁に 2 型進行胃癌を指摘され, 当院紹介となった。精査で左肝に $10-$ $15 \mathrm{~mm}$ の転移を 4 個, $10-26 \mathrm{~mm}$ の多数の所属リンパ節転移, 傍 大動脈リンパ節の腫大を認め, T 4 aN 3 M 1, Stage IV と診断し た. 根治手術は困難と考え, S- 1+シスプラチン療法 5 コース後, 原発巣は著明に縮小し肝転移巣および傍大動脈リンパ節腫大は消 失した. 治癒切除の可能性があり幽門側胃切除 D 2 及び左肝切除 を施行した，腫瘍は体下部前壁に白色瘏痕として認めた，術前転 移と考えたリンパ節は膵実質に固着していたが剥離可能だった. 病理所見では $25 \times 25 \mathrm{~mm}$ の 0 - I 型病変と $0-$ II c 型様の瘏痕を認 め, 前者は高分化型管状腺癌 (tub 1) が主体でporが隣接し, 後者は腫瘍細胞を認めなかった．切除肝にも腫瘍細胞を認めず,
術前転移リンパ節のほとんどが消失し, No. 6 の 1 個のみ病変が 残っていた，術後に化学療法も再開し経過観察中である。

\section{0 進行胃癌に対する腹腔鏡下胃切除術の周術期成績の検討} 北海道大学消化器外科 I

渋谷一陽、川村秀樹、大野陽介、市川伸樹、吉田 雅、本間重紀、 武富紹信

背景：腹腔鏡下胃切除術 (LG) は急速に普及が進んでいるが、 多くは早期胃癌に対するものであり進行胃癌おけるLGのエビデ ンスはまだ少ない。そこで当科で施行した進行胃癌に対するLG の周術期成績を、同じく進行胃癌に対して開腹胃切除術 (OG) を施行した症例と retrospectiveに比較検討した。

対象：2008年 1 月から2016年 3 月までに当科で施行した進行胃癌 症例 OG34例とLG42例に扔いて、幽門側胃切除、胃全摘別に術中、 術後因子を比較した。Stageは胃癌取り扱い規約第14版に統一し、 合併症はClavien-Dindo 分類 Grade III 以上とした。

統計学的検討には、カイ 2 乗検定およびStudent-t検定を用い、 $\mathrm{p}<0.05$ を統計学的有意差ありとした。

結果：開腹幽門側胃切除術 (ODG) 13例vs腹腔鏡下胃切除術 （LDG）23例において手術時間中央值は197分 vs268分（p=0.0041） と LDGで長く、出血量は $150 \mathrm{mlvs} 35 \mathrm{ml}(\mathrm{p}=0.0118)$ と LDGで少 なく、郭清リンパ節個数は27個 vs49個（p=0.0003）と LDGで多 かった。また、LDGに打ける開腹移行症例はなかった。術後 1 日目のCRPは6.68vs4.65（p=0.0152）と LDGで低かった。術後合 併症率 $(0 / 13 \mathrm{vs} 2 / 23)$ に差はなかった。術後在院日数は18日 $\operatorname{vs} 12$ 日 ( $\mathrm{p}=0.0323)$ とDGで短期間であった。開腹胃全摘術 (OTG) 21例 vs 腹腔鏡下胃全摘術（LTG）19例において手術時間（258分 vs281分）は差を認めなかったが、出血量は240mlvs50ml （ $\mathrm{p}=0.0036 ） と \mathrm{LTG}$ で少なかった。郭清リンパ節個数（35個 vs38 個）に差はなく、LTGにおける開腹移行症例はなかった。術後 1 日目のCRPは7.61vs3.78（p=0.0007）と LTGで低かった。術後 合併症発生率（1/21vs $1 / 19)$ 、術後在院日数（18日 vs14日）は OTGとLTGで差を認めなかった。再手術はすべての群で認めな かった。

結語：進行胃癌に対するLGはOG と比較し周術期成績で劣るこ となく安全に施行可能であった。今後は長期成績に関する検討が 必要である。

11 腸閉塞にて発症した小腸狭窄の一例

砂川市立病院消化器外科

河北一誠、本間友樹、太刀川花恵、松井博紀、細田充生、横田良 一、田口宏一

症例は75歳男性。腹痛と嘔気を主訴に来院した。腹部 CT検查で 小腸に 2 か所の狭窄病変とそれより口側での腸管拡張を認め、腸 閉塞の診断であった。保存的加療にて症状は改善したが、流動食 の開始で腹痛が再燃した。小腸内視鏡での精查を検討したが、狭 窄部の内視鏡通過が困難と判断され、診断的治療目的に腹胿鏡補 助下での手術による病変部摘出の方針とした。術中所見では回腸 末端より約 $1 \mathrm{~m}$ 口側と、それより約 $15 \mathrm{~cm}$ 口側の回腸に病変を認 め、両者を含む範囲での小腸部分切除術を施行した。摘出標本で は 2 か所に潰瘍性病変を認め、これによる症状であったと推察さ れた。術翌日より飲水を開始し、術後 2 日目から食事摂取を開始 したが、症状の再燃なく経過している。今回、我々は腸閉塞にて 発症した小腸狭窄の一例を経験した。肉眼的には多発小腸潰瘍と 推察されたが、その原因および治療方針に関して、病理結果およ び文献的考察を交えて報告する。 
12 術前診断が困難であった小腸脂肪腫茎捻転の 1 例 小林病院外科

助川 誠、山本康弘、木田裕之、重原健吾

症例は54歳、男性。2016年 2 月、腹痛を主訴に当院を受診した。 $\mathrm{CT}$ 検查にて上行結腸悡室、腹垫内腫瘤像を認め、榎室炎疑いで 内科にて保存的治療を行った。症状改善したが、腹腔内腫瘤像に は著変なく、放射線科読影にて腸間膜捻転を疑われ手術治療目的 に当科へ紹介となった。腹胿内を観察すると、回腸末端から $140 \mathrm{~cm}$ 口側の回腸に連続する有茎性の腫瘤を認めた。茎部で捻転 しており、腹䏶鏡下に腫瘤切除術を施行した。病理組織検查で壊 死性変化を伴う脂肪腫と診断された。7 POD に退院し、経過旅 行である。小腸腫瘍は消化管腫瘍のうちわずか 1 ～ $2 \%$ を占める のみで、そのうち良性のものは $30 \%$ 程度である。良性腫瘍では GISTが最も多いが、脂肪腫は良性腫瘍の $2.6 \%$ であり、まれな腫 瘍である。脂肪腫の腸管壁における占居部位は，粘膜下にあるも のが76\%、漿膜下が $12 \%$ 、その他 $12 \%$ 。ほとんどが単発性であり、 小腸脂肪腫の茎捻転の報告はわが国で 1 例あるのみで、極めて稀 である。今回我々は、茎捻転をきたし手術治療が必要であった小 腸脂肪腫の 1 例を経験したため、若干の文献的考察を交えて報告 する。

13

縦隔・肺門リンパ節転移を伴った小腸未分化癌の 1 例 製鉄記念室蘭病院外科・呼吸器外科 1 同病理診断科 ${ }^{2}$

飴田咲貴 ${ }^{1} 、 千$ 葉龍平 ${ }^{1}$ 、宮坂 衛 ${ }^{1} 、$ 佐藤彰記 1 、大高和人 1 、東海 林安人 1 、長谷龍之介 1 、市村龍之助 1 、仙丸直人 1 、藤田美悧 2 症例は70代女性。腹部緊満感と鈍痛を主訴に当院を受診、腹部 CT で下腹部の腫瘤と左縦隔・肺門部の腫瘤影を認め、採血上 sIL-2 Rが高值であった。悪性リンパ腫又は小腸癌を疑ったが内 視鏡的に生検困難であり、診断目的に開腹術を施行し骨盤垫内に $15 \mathrm{~cm}$ 大の空腸腫瘍を認め切除した。病理組織では大型で未分化な 異形細胞が浸潤性に増殖していた。免疫染色では AE 1/AE 3、 vimentinなどが陽性であり小腸原発未分化癌と診断した。術後 2 週間で $\mathrm{CT}$ 上縦隔・肺門部腫瘤影の急速な増大があり、気管支 鏡下生検を実施したところ小腸未分化癌のリンパ節転移と診断さ れた。大腸癌に準じFOLFOX+Bmabで化学療法を開始したとこ ろリンパ節病変の縮小を認め、術後 5 か月を経過し無増悪生存中 である。

小腸原発覀性腫瘍は非常に稀であり、中でも未分化癌は極めて珍 しく予後不良である。今回我々は縦隔・肺門リンパ節転移を伴っ た小腸未分化癌の 1 例を経験したので文献的考察を含めて報告す る。

\section{4}

生体肝移植後の内ヘルニアにより小腸穿孔を発症した

1 例

北海道大学病院消化器外科学分野 $\mathrm{I}^{1}$ 、北海道大学移植外科 ${ }^{2}$ 、北 海道大学病院臓器移植医療部 3

中本裕紀 1 坂本 譲1 後藤了一1 $、$ 腰塚靖之 1 、川村典夫 1 、太田 稔 1 、

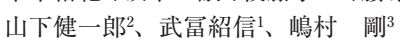

【症例】60代男性。2008年C型肝硬変に対し生体肝移植施行。結 腸前経路 R-Y 法で再建した。術後 3 年より繰り返す腸閉塞を認 めるも保存的に軽快。本年 3 月腸閉塞再発しイレウス管造影で狭 窄病変からの流出無く、イレウス解除術を予定。入院 6 日目に急 激な腹痛、腹膜刺激症状と CTにて free airを認め、緊急開腹術 を施行。開腹所見で癒着無く、Y脚と結腸間膜間隙への内ヘルニ アと Y 脚腸管の捻転・穿孔を認めた。内ヘルニア整復後に穿孔部
位を含む $\mathrm{Y}$ 脚を約 $5 \mathrm{~cm}$ 切除再建し、ヘルニア門を閉鎖した。術 後45日目に退院した。【考察】肝移植後は免疫抑制療法により癒 着が生じにくく、 $\mathrm{R}-\mathrm{Y}$ 再建に起因した内ヘルニアのリスクがあ る。迷入腸管のみならず拳上脚の血流障害は胆管空腸吻合部を障 害し得るため早期の診断・治療方針の決定が必要である。【結語】 肝移植後 $\mathrm{R}-\mathrm{Y}$ 胆道再建では内ヘルニア発症を考慮し、原因とな る拳上脚腸間膜部の十分な閉鎖や結腸後経路の選択が対応策とな る。

15 小腸イレウスに対する待機的な腹䏶鏡手術の完遂症例 の検討

イムス札幌消化器中央総合病院消化器外科1、愛育病院外科 2 、旭 川赤十字病院外科 ${ }^{3}$

鈴木 温 ${ }^{1,2}$ 、蔵前太郎1,3、三橋洋介 ${ }^{1}$ 、渡会博志 1 、越湖 進 ${ }^{1}$

【目的】小腸イレウスに対して、待機的な腹腔鏡手術を施行した 症例の治療成績の検討を行った。【対象】2013年から2016年 3 月 まで小開腹併用を含む腹腔鏡手術を行った 10 例。全例イレウス管 にて腸管減圧され、術前検查で閉塞部位が同定された症例に対し て待機的手術を行った。【結果】男性 5 例、女性 5 例、年齢68歳 (以 下中央值)。手術時間100分、イレウス管挿入から手術まで 9 日。 開腹歴は、なし 5 例、あり 5 例。閉塞機転は、癒着 5 例、索状物 3 例、悪性腫瘍 1 例、腸間膜内ヘルニア 1 例であった。術式は、 癒着剥離、索状物切離 8 例、腸切除は 2 例に行った。術中、腸管 漿膜損傷を 2 例に来たし、小開腹にて損傷部の確認、漿膜縫合を 要した。完全腹腔鏡手術 7 例、 $3-4 \mathrm{~cm}$ の小開腹併用を 3 例に施 行した。術後合併症はなく、食事摂取 4 日、術後在院期間11日た った。イレウスの再発は認めていない。【結語】小腸イレウスに 対する腹腔鏡手術は、有効な治療の選択肢となりうる。

16 黒色便を契機に発見された小腸槳膜下脂肪腫 旭川医科大学外科学講座消化器病態外科学分野1、旭川医科大学 病院病理部2

大谷将秀1、庄中達也、長谷川公治1、大原みずほ 1 、宮本正之 1 、 谷 誓良1、浅井慶子1、武井英博2、古川博之 ${ }^{1}$

小腸脂肪腫は稀な疾患で多くは粘膜下に発生し、大きな病変は腸 重積を合併する頻度が高いとの報告もある。今回腸重積を合併せ ず黒色便を契機に発見された回腸漿膜下脂肪腫を経験した。症例 は51歳男性。黑色便を認め、上・下部消化管内視鏡を施行したが 出血源はなかった。翌年再び黒色便を認めカプセル内視鏡で回腸 に腫瘍性病変を認めた。ダブルバルーン内視鏡で回腸に $30 \mathrm{~mm}$ 超 の有茎性腫瘍を認め、CTで脂肪腫を疑い手術の方針となった。 手術は単孔式腹胫鏡補助下で行い、病変肛門側の点墨を同定し小 腸部分切除した。肉眼所見では $5 \times 1.2 \times 1.2 \mathrm{~cm}$ の有茎性ポリープ 状腫瘍を認め、病理組織学的診断は漿膜下脂肪腫であった。術後 経過良好で第 8 病日に退院した。小腸脂肪腫は内視鏡的切除の選 択肢もあるが、漿膜下に発生する症例があり、術前に内視鏡や超 音波内視鏡等で存在部位を確認することは有用である。また腸重 積を合併しない小腸脂肪腫においては術前の局在診断が病変同定 に有用であった。 
17 腹腔鏡下で治療し得た小腸型Chilaiditi症候群による イレウスの一例

市立旭川病院外科

阿部紘丈、村上慶洋、宮坂 衛、福永亮朗、笹村裕二、武山 聡、 沼田昭彦、子野日政昭

症例は84歳女性、腹部膨満、嘔気、嘔吐を主訴に当院を受診。来 院時のCTで右横隔膜下と肝臓の間に拡張した小腸が確認され Chilaiditi症候群によるイレウスと診断された。絞扼を疑う所見 などなく、イレウス管を留置し保存加療を先行させた。腸管の減 圧は得られたがイレウス症状の改善には至らず、腹腔鏡下イレウ 又解除術を施行した。手術所見では、肝と腹膜、右横隔膜間に線 維性の索状物形成を複数認め、右横隔膜下に回腸が嵌入 ·狭窄し ていたが、壊死は認めなかった。術後 2 日目より食事再開、6 日 目に退院となった。小腸型Chilaiditi症候群は絞扼性イレウスを 来たすこともあり、緊急手術が必要となる場合もある。しかし、 本症例の様に術前診断がつけば、減圧を施行したのちに鏡視下手 術を施行することが可能であり、術後の早期回復が期待できる。 今回我々は腹腔鏡下で治療し得た小腸型Chilaiditi症候群による イレウスの一例を経験したので文献的考察を加え報告する。

\section{8 下腸間膜静脈腫瘍栓を伴った $\mathrm{S}$ 状結腸癌の 1 切除例} 勤医協中央病院外科

諸星直輝、吉田 信、石井健一、杤寉 藍、奈良智志、澤崎兵庫、 阿部慎司、田尾嘉浩、川原洋一郎、林 浩三、後藤 剛、山川智 士、鎌田英紀、高梨節二、樫山基矢、松毛真一、河島秀昭 症例は68歳男性. 3 週間前より左下腹部痛が出現し当院を受診し た．腹部 CT で $\mathrm{S}$ 状結腸の壁肥厚と下腸間膜静脈内の塞栓を認め た．大腸内視鏡前処置のため下剂を内服したところ下腹部痛と嘔 吐が出現した. 大腸内視鏡で $\mathrm{S}$ 状結腸に全周性の 2 型腫瘍を認め, その口側結腸は脾弯曲部まで全周性に発赤し浮腫状であった，S 状結腸癌, 静脈腫瘍栓, 虚血性大腸炎の診断で結腸左半切除 D 3 を施行した．腫瘍の周囲への浸潤は認めず，腸間膜は肥厚してお り腫瘍栓を索状物として触知した。下腸間膜静脈は脾静脈合流部 で結紮切離した，病理所見は $60 \times 50 \mathrm{~mm}$ の中分化型管状腺癌で, 浸潤は漿膜下層までであった。多数の静脈浸潤と，下腸間膜静脈 内に腫瘍栓を認めた。リンパ節転移は認めなかった。腫瘍の口側 腸管に虚血性大腸炎に伴う縦走潰瘍瘕痕を認めた。下腸間膜静脈 腫瘍栓を伴った $\mathrm{S}$ 状結腸癌の 1 切除例を経験したため若干の文献 的考察を加えて報告する。

\section{9 腹膜偽粘液腫に対して術中温熱化学療法を施行した 2 例} 市立室蘭総合病院

中山健太、齋藤慶太、奥谷浩一、中野正一郎、待木隆志、佐々木 賢一

腹膜偽粘液種はまれな疾患で、粘液癌が腹腔内に播種し、腹腔内 に多量の粘液が貯留した病態である。その頻度は 100 万人に 1 人 から 2 人と言われており、きわめて稀な疾患である。原因は虫垂 粘液囊腫であることが多く、その発育は一般的には緩徐である。 腹腔内に限局し、遠隔転移を起こすことは通常はないが、最終的 には臟器障害をきたし致死的となる。治療としては、欧米におい ては完全減量切除+腹垫内温熱化学療法が広く受け入れられてい るが、本邦では姑息的な減量手術と全身化学療法が行われている ことがほとんどである。今回、当院にて腹膜偽粘液腫に対して減 量切除術と術中温熱化学療法を施行した 2 例を経験したので若干 の文献的考察を踏まえて報告する。
20 腹壁浸潤のある上行結腸癌に対して、術前化学放射線 療法で病理的寛解が得られた 1 例

手稲溪仁会病院外科 1 、同病理科 ${ }^{2}$ 、同放射線治療科 ${ }^{3}$

関谷 翔1、今村清隆1、西 智史 1 、篠原良仁 1 、伊橋卓文 1 、横山 新一郎1、水沼謙一1、吉見泰典1、武内慎太郎1、寺村紘一1、田畑 佑希子 1 、阿部 大 1 、早馬 聡 1 高田 実 1 小ノ下義宏1、加藤 弘明1、安保義恭1、中村文隆1、成田吉明1、樫村暢一1、松波已1 野口寛子 2 、三浦勝利 ${ }^{3}$

【はじめに】大腸癌の放射線療法に関しては直腸癌に対する術前 の腫瘍量減量、術後の再発抑制や肛門温存が目的であり、上行結 腸癌の生存率の有意な改善を認めるエビデンスは十分ではない。 この度腹壁浸潤を疑う上行結腸癌に対する術前化学放射線療法の 後に腫瘍を切除したところ、病理的寛解が得られていた症例を経 験したため報告する。【症例】65歳女性。最近の医療機関の受診 歴なし。数ヶ月の活動性低下、腹部腫瘤、るい瘦を主訴に、救急 外来を受診。 $\mathrm{Hb} 2.9 \mathrm{~g} / \mathrm{dL}$ と高度貧血を認めて入院精查行い、腹 壁浸潤を伴う上行結腸癌と診断された。化学療法 (Panitumumab+mFOLFOX 6) 5 コース施行後 2 か月のCTで は腫瘍の縮小を認めたが、更に 4 コース後には腫瘍増大し腹水出 現しPDの判定となった。化学療法の効果なく、副作用出現にて、 局所制御目的に放射線療法 $(60 \mathrm{Gr} / 30 \mathrm{Fr})$ を施行したところ、腫 瘍の縮小を認めた。当科にて 1 か月後に開腹右半結腸切除術、 D 3 郭清を施行し、術中所見では腹膜浸潤を疑う所見を認めなかっ た。合併症なく 7 日で退院。検体の病理検査では切除した腫瘍内 に明らかな癌の残存なく、リンパ節転移も認めず、組織学的治療 効果判定はGrade 3 (pCR) 相当であった。【結語】放射線療法 は現在直腸癌治療において補助的・緩和的役割を担っているが、 腹壁浸潤を伴う手術困難な上行結腸癌の症例においても、術前の 放射線療法を先行することで腫瘍の縮小効果が期待できるため、 局所浸潤型の上行結腸癌の治療選択肢として積極的に放射線療法 を考虑すべきである可能性が示された。

21 術前の血行動態把握によって安全に切除可能であった 腹腔動脈・上腸間膜動脈狭窄症を伴う横行結腸癌の 1 例 独立行政法人地域医療機能推進機構北海道病院外科 矢部沙織、坂本聡大、敦賀陽介、正村裕紀、中西一彰、数井啓蔵 症例は66歳、男性。腹痛を主訴に当院を受診した。下部消化管内 視鏡検查で横行結腸脾弯曲部に全周性の 2 型腫瘤を認め、生検の 結果は adenocarcinoma,por-sigであった。造影 CT 検查を施行し たところ、動脈硬化の所見が強く、腹腔動脈根部の閉塞と上腸間 膜動脈起始部の $90 \%$ 狭窄を認め、下腸間膜動脈は著明に拡張して いた。腹部血管造影検查を施行したところ、腹胿動脈・上腸間膜 動脈が起始部で閉塞し、下腸間膜動脈が代償性に発達し、左結腸 動脈、脾彎曲部辺縁動脈、膵背動脈、腹腔動脈へと逆行性に血流 を供給していた。選択的上腸間膜動脈造影では、膵頭部アーケー ドを介して総肝動脈が造影され、下腸間膜動脈がほぼ全ての消化 器系の腹㘶内臓器へ血流を供給していた。横行結腸癌（T 4 aN 0 M 0 cStage II）の診断で、横行結腸切除術、D 2 郭清を施行した。 血行再建も念頭に置いたが、術中所見で辺緣動脈が中結腸動脈側 へ分岐した直後に腫瘍が存在し、分岐部で血管処理可能であった。 術後経過は良好で術後 9 日目に当科退院、術後 27 月月経過し無再 発生存中である。大腸癌に腹部動脈狭窄が合併した症例では、結 腸動脈の切離により広範な腸管壊死、腹埶内臓器の虚血をきたす 可能性がある。大腸癌手術においては、術前画像検査により十分 な腹部血管の血行動態の評価が重要である。 
22 上行結腸㮩窒穿孔に合併した若年発症腸管囊胞性気腫 症の 1 例 旭川赤十字病院

青柳裕之、真名瀬博人

【背景】腸管囊胞性気腫症 (pneumatosis cystoides intestinalis:PCI）は、腸管壁内に多発性の含気性囊胞を形成する 比較的稀な疾患である。また、通常悡室穿孔は組織が脆弱化する 高龄者に多くみられ、若年者での報告は少ない。今回我々は、上 行結腸想室穿孔に合併した若年発症PCIの 1 例を経験した。

【症例】16歳男性。右下腹部痛を主訴に来院した。腹部軟、筋性 防御なし。WBC 14,830/ $\mathrm{mm}^{3}, \mathrm{CRP} 1.699 \mathrm{ng} / \mathrm{dl}$ 。腹部CTでは虫 垂の腫大や明らかな悡室炎の所見は認めず、回腸末端に浮腫状変 化を認めたため回腸末端炎を疑い消化器内科入院となった。入院 後 2 日目、腹痛の增強、WBC $22,670 / \mathrm{mm}^{3}, \mathrm{CRP} 30.838 \mathrm{ng} / \mathrm{dl}$ と 炎症反応の増悪を認めた。再度 CT検查を行ったところ、肝周囲 にfree airを認め、上行結腸から回盲部にかけて周囲脂肪織濃度 上昇、膿湯形成を認めたため、回盲部付近での穿孔を疑い緊急手 術を施行した。腹腔鏡下で上行結腸に径 $2 \mathrm{~cm}$ 程の穿孔を認めた。 炎症高度で腹望鏡操作続行困難と判断し開腹移行した。バウヒン 并遠位側約 $2 \mathrm{~cm}$ に穿孔を認め、穿孔部位より $2 \mathrm{~cm}$ 肛門側で上行 結腸を切除し回腸末端から約 $10 \mathrm{~cm}$ 近位側で小腸を切除し端側吻合 を行った。病理検査では上行結腸の壁内に気泡構造が多発してお り、内䏶に突出する腫瘤を認婸管囊胞性気腫症の所見と㰾室穿 孔と診断された。

【術後経過】術後炎症反応や腹部所見は徐々に改善し術後17日目 に退院となった。

【考察】PCIは高濃度酸素療法により保存的治療を行うことで改 善したとの報告がある一方、free airを伴うこともあるため消化 管穿孔が疑われ開腹手術が行われたとの報告もある。今回我々は、 上行結腸悡室穿孔に合併した若年発症PCIの 1 例を経験したので 若干の文献的考察を加え報告する。

23 S状結腸息窒穿孔をきたしたEhlers-Danlos syndromeの一例

札幌医科大学消化器 - 総合、乳腺 - 内分泌外科

石井雅之、沖田憲司、西舘敏彦、植木知身、伊東竜哉、秋月恵美、 信岡隆幸、古烟智久、竹政伊知朗

【はじめに】今回、我々はS 状結腸悡室穿孔をきたしたEhlersDanlos syndrome(以下EDS)の 1 例を経験したので報告する。症 例】37歳、女性。腹痛を主訴に前医を受診。腹部 CTで $\mathrm{S}$ 状結腸 の多発憩室と腹腔内の fluid を認め、S 状結腸憩室穿孔による腹腔 内膿瘍の診断となった。EDSにて当院通院中であったため当院 転院となった。腹膜刺激症状を呈していなかったため、保存的加 療を行ったが、加療中に腹膜刺激症状を認めたため緊急手術を施 行した。【手術】皮膚は薄く縫合結紮でも裂創を生じ、腹㬶内組 織も脆弱であり毫引で容易に損傷をきたした。また、電気メスに よる凝固止血の際でも止血を得る前に周囲組織が損傷し更なる出 血を惹起した。吻合は危険であると判断し、S 状結腸切除術、人 工肛門造設術を施行した。術後、SSIに対する加療を要したが致 死的な合併症をきたさずに治癒に導き得た。【まとめ】S 状結腸 悡室穿孔をきたしたEDSの一例を経験したので、文献的考察を 加えて報告する。
24 胆管ステントによるS 状結腸穿孔の 1 例 市立旭川病院外科

宮坂 衛、阿部紘丈、村上慶洋、福永亮朗、笹村裕二、武山 聡、 沼田昭彦、子野日政昭

症例は82歳、男性。 2 年前に当院にて総胆管結石による胆管炎に 対して、プラスチック胆道ステントによる内視鏡的胆道ステント 留置術（EBS）を施行していた。朝からの腹痛で近医を受診し、 腹部 CT 検查にて S 状結腸で逸脱した胆管ステントを認めた。一 部が腹腔内に突出しており、穿孔の可能性が考えられた。当院に 救急搬送され、緊急開腹手術を施行した。手術所見ではS 状結腸 に穿孔したステントを認めたが、周囲の腹水の污染や便の流出な どは認めなかった。ステントを抜去の後に、穿孔部位の局所切除 術を施行した。EBSは比較的安全な手技であるが、晚期偶発症 の 1 つであるステント逸脱やそれによる消化管穿孔などがしばし ば経験される。中でも逸脱したステントによる結腸穿孔は比較的 稀であるため、若干の文献的考察を加えて報告する。

25

の有用性

市立函館病院消化器外科

笠島浩行、加藤紘一、長瀬勇人、植木伸也、佐藤利行、久留島徹 大、砂原正男、鈴木伸作、中西一彰、木村 純

【はじめに】ハルトマン手術後のストーマ閉鎖はループ式ストー マとは異なり, 体内の肛門側断端の剥離や口側腸管の授動が必要 である. 当院では近年, ハルトマン術後ストーマ閉鎖に腹腔鏡手 術（以下, LAP) を行っている. 今回, 開腹手術（以下, OS) との成績を比較する.【対象と方法】2006年から行われたストー マ閉鎖術72例うちハルトマン手術後の閉鎖27例を対象にLAP と OSを比較検討.【術式】ストーマ部腸管を全周性切開し腹壁と分 離切除後, この穴に Ezアクセスを装着して気腹. 腹腔鏡操作で 結腸断端から口側の剥離授動と肚門側の断端を剥離露出し自動吻 合器で吻合.【結果】LAPは11例（平均62.3歳, 男 5 : 女 6), OSは16例（66.6歳, 男 10 ：女 6)。手術時間はLAP 205.4分:OS 218.1分, 出血量はLAP $19.5 \mathrm{ml}:$ OS $210.9 \mathrm{ml}$, 術後在院日数はLAP 8.5日：OS 20.1日. 術後合併症はLAPなしでOSでは術後イレウ ス 3 例であった.【まとめ】ハルトマン手術後のストーマ閉鎖術 に扔いてLAPはOSょり短期成績は極めて良好である.

26 経肛門的イレウス管による腸管穿通後に癌性腹膜炎を 発症した閉塞性直腸癌の一例

国立病院機構函館病院外科 1 、同消化器内科 ${ }^{2}$ 、同病理診断科 ${ }^{3}$ 城崎友秀 1 、山吹 匠 1 、岡村国茂1、藤原 晶、高橋 亮 1 、小室 一輝 1 、岩代 望1、木村伯子 3 、間部克裕 2 、大原正範 1 、加藤元嗣 2 症例は77歳, 男性. 平成 27 年 7 月に閉塞性直腸癌に対し経肛門的 イレウス管を留置した後に腹腔鏡下高位前方切除を施行した. 術 中にイレウス管の穿通を認めたものの明らかな腹膜転移所見は認 めず, 病理結果はpT 3 (SS) N O H O P 0 M 0, pStage II で術後 化学療法は行わず経過観察方針となった. 術後 7 ケ月となる平成 28年 2 月に便秘を発症し下部消化管内視鏡検査を施行したとこ ろ, 吻合部に全周性の狭窄を認姓検にて adenocarcinomaの診 断となり再発と判断した. 切除目的に手術を施行したところ, 腹 膜・小腸間膜に多数の結節を認め癌性腹膜炎の診断となった. 腹 膜炎の影響で骨盤内臓器が一塊となっており回腸の狭窄をきたし ていたため口側回腸にて人工肛門を造設し終了した。術後 6 日目 から食事再開したが, 敗血症をきたし術後16日目に永眠された. 
本症例はイレウス管穿孔による腹膜転移をきたした可能性が高い と考えられる。イレウス管による腸管穿孔の報告は散見されるも のの腹膜転移をきたした症例は非常に稀であり報告する.

\section{7 開腹にて摘出しえた直腸内異物の 1 例} 札幌医科大学医学部医学科 5 年 1 、北海道社会事業協会余市病院外 科 2

橋野結子 1,2 、那須裕也 2 、横山和之 2 、吉田秀明 2 症例は51歳男性. 精神疾患で施設に入所中の方. 検診で便潜血陽 性であったため他院で大腸カメラを施行したところ，肛門から 10 $\mathrm{cm}$ の位置で硬い棒状の固形物を認め, 内視鏡では摘出不可能と判 断され当院へ紹介された。レントゲン写真でトロフィーの先端部 分と思われる異常像を認めた。 また診察では肚門括約筋は緩く, 以前から同様の行為を繰り返していたと考えられ，また固形物は 触知できるものの可動性がなかった．そのため手術室での摘出の 方針とした．初めに筋弛緩導入後経肛門的に摘出を試みたが，可 動性は全くなく断念．引き続き開腹手術を行い, 直腸を切開して 摘出を試みたが, トロフィーの両手の部分が腸管に刺さるように して存在したため, 手を切断した後に摘出し, 腸管縫合ならびに $\mathrm{S}$ 状結腸人工肛門造設術を施行した。

\section{8} 経肛門的に挿入したプラスドライバーにて直腸穿孔を きたした 1 例 函館協会病院外科 1 札幌医科大学消化器総合、乳腺 - 内分泌外 科2

久木田和晴 ${ }^{1}$ 村上武志 ${ }^{1}$ 、澤田 健 ${ }^{1}$ 、向谷充宏 ${ }^{1}$ 竹政伊知朗 ${ }^{2}$ 症例は76歳男性、既往歴として躁うつ病にて近医精神科通院中で あった。妻が亡くなって以来、性的刺激がなくなり自慰行為目的 にて肚門より異物を挿入していた。今回、プラスドライバー挿入 後、抜去困難となり、1 週間放置していたが、違和感が強くなっ たため近医受診、経肍門的摘出は困難と判断され当科紹介となっ た。血液検查では炎症反応高值を認めたものの、腹痛は認めず、 腹部 CTでは直腸から右臂部におよぶ高吸収体を認めた。腹䏶内 にfree air および腹水は認めず、腹膜翻転部肛門側で穿孔したと 判断した。経肛門的摘出は不能な状沉であり、全身麻酔下に緊急 手術を施行した。右臂部は発赤硬結を認め、炎症反応も高值であ った事から、フルニ工症候群への移行も懸念され、異物先端部の 皮膚を切開し異物摘出の上、S 状結腸人工肛門造設㧍よび穿孔部 周囲組織のデブリードマンにSeton 法を付加した。摘出された異 物は約 $20 \mathrm{~cm}$ のプラスドライバーであった。

術後は速やかに炎症反応も改善、問題なく経過し退院となった。 現在外来にて経過観察中であるが、今後、人工肛門閉鎖予定であ る。経肛門的直腸異物は、偶発的な事故や性的嗜好あるいは精神 障害により肛門から異物が挿入され、抜去不能となったものであ る。近年、直腸異物による報告が散見されており、今後も増加し、 実臨床上遭遇する可能性がある。直腸異物に対しては、異物内容、 穿孔の有無、穿孔部位を正確に判断し、適切な治療、手術を選択

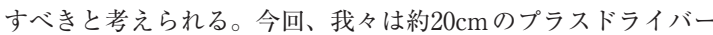
を経肍門的に挿入し、直腸穿孔をきたした 1 例を経験したので、 若干の文献的考察を加え報告する。
29 上腕動脈瘤に起因する左上肢急性動脈閉塞症の 1 例 名寄市立総合病院心臟血管外科

中津知已、眞岸克明、清水紀之、和泉裕一 症例は71歳男性で, 主訴は 3 日前からの左前腕のしびれであった. 小児麻痺で左下肢麻痺があり日常生活で松葉杖を使用していた. $\mathrm{CT}$ 検查で左上腕動脈瘤と上腕動脈閉塞を認め当科紹介となっ た. 左上肢急性動脈閉塞症の診断で同日, 緊急手術を行った。動 脈瘤は腋窩に近く，常に松葉杖の圧迫に曝されており皮膚性状は 不良であったので, 左上肢動脈血栓摘除術と動脈瘤空置バイパス 術を行う方針とした. 手術は全身麻酔下に左上腕動脈を切開して 血栓摘除術を行った，次いで, 腋窩動脈を中枢吻合とした上腕動 脈バイパス術を行った，バイパスグラフトは大伏在静脈を使用し た. 動脈瘤は, 瘤の可及的近傍で動脈を結紫して空置した. 術後 CT 検査では, 空置瘤に僅かに血流を認めたが, バイパスグラフ 卜，上腕から前腕の動脈も開存しており良好な経過であった。 上 腕動脈瘤は稀な疾患であるが, 本症例では松葉杖による慢性的な 外力が瘤の原因であったと推察された。

30 原因不明の腹水に対し審查腹腔鏡で腹膜悪性中皮腫と 診断しえた一例

イムス札幌消化器中央総合病院消化器外科 ${ }^{1}$ 、愛育病院 ${ }^{2}$ 、旭川赤 十字病院 ${ }^{3}$

三橋洋介 ${ }^{1}$ 、鈴木 $\quad$ 温 ${ }^{2}$ 、渡会博志 ${ }^{1}$ 、蔵前太郎 3 、越湖 進 ${ }^{1}$ 症例は50代男性. 職業歴として, 34歳時より, トラックの運転業 務に従事し，建物の解体現場で仕事をしている。頻尿と下腹部の 違和感があり, 近医泌尿器科を受診した. 腹部超音波検查行い, 大量の腹水貯留を認めた．精查目的に当院を紹介となったＣT 検查では, 腹水貯留と大網の肥厚がみられた。胸水貯留は認めな かった，PET検査では， CT検查でみられた腹水貯留の部位に一 致して，腹水にびまん性の淡い集積が認められた。しかし明らか な腹膜病変や腹部骨盤内の腫瘍性病変を認めなかった。腹水穿刺 検查行い, 細胞診では class III. 腹水生化学所見では, ヒアルロ ン酸高值であり，ADA は基準範囲内であった，腹水細菌培養検 査は陰性であった，確定診断に至らず，審査腹䏕鏡を行った，腹 腔内は, 黄緑色の粘性の高い腹水が大量に貯留しており, 腹膜全 体に $2-15 \mathrm{~mm}$ 大の不整形の白色結節を多数認めた. 特に, 結節 は大網に集中してみられたが, 腸管壁には無かった。腹水を十分 量採取し, セルブロック検体を作成し, 大網の一部と腹膜結節も 採取し, 免疫染色を行った。免疫染色では, 悪性中皮腫の陽性マ ーカーである calretininが陽性で, 癌の鑑別マーカーのCEA, TTF-1 が陰性となった．組織学的所見は, 比較的均一な大型の 細胞が, 結節状に増生している様子が認められ, 腹膜悪性中皮腫 の診断であった。術後経過良好にて, 術後第 5 病日に退院した。 化学療法目的に専門施設への紹介とした. 現在は初診から 4 ケ月 経過しており, シスプラチン+ペメトレキセドを用いた化学療法 を継続中である.

原因不明の腹水の診断に審查腹䏕鏡が有用であった症例を経験し た. 文献的考察を加えて報告する. 
31 多中心性後腹膜脂肪肉腫の 1 例 札幌センチュリー病院外科、札幌医科大学医学部第二病理学講 座 $^{2}$

小西和哉1、坂本 尚1、安原満夫1、永㴊 誠、田中 敏 ${ }^{2}$ 多中心性後腹膜脂肪肉腫は稀である。自験例を報告する。症例は 82 歳女性。主訴 : 腹部膨満感、膀胱脱出感。現病歴 : 1 年前から 腹部膨満感自覚。3 ケ月前から頻尿、尿失禁。1 个月前から腹部 膨満感が増悪した。既往歴：虫垂炎13歳、子宮筋腫50代。現症： $147 \mathrm{~cm} 、 64 \mathrm{~kg}$ 、腹囲 $104 \mathrm{~cm}$ 。CT : 右後腹膜に $25 \mathrm{~cm}$ 大の造影効果 の乏しい脂肪濃度の腫瘍、左後腹膜に $25 \mathrm{~cm}$ 大の造影効果の乏し い充実性腫瘍を認め両側腫瘍により腸管は圧排されていた。 MRI : 右後腹膜腫瘍は脂肪抑制 T 1 強調像で均一に脂肪抑制を受 け、高分化脂肪肉腫の所見。左後腹膜腫瘍は脂肪抑制効果が不均 一で $\mathrm{T} 2$ 強調像で軽度高信号。粘液脂肪肉腫が混在している可能 性があった。拡散強調像で有意高信号はなかった。後腹膜脂肪肉 腫の診断で手術施行。手術所見 : 右後腹膜腫瘍と右側結腸との剥 離は比較的容易だったが右尿管、右総腸骨静脈とは剥離困難であ った。左後腹膜腫瘍は S 状結腸に浸潤所見あり合併切除した。左 右の腫瘍に交通はなかった。右側腫瘍は $26.6 \times 29.5 \times 10 \mathrm{~cm}$ 、 $3.05 \mathrm{~kg}$ 、病理診断は well differentiated liposarcoma、左側腫瘍は $23.5 \times 30 \times 7.5 \mathrm{~cm} 、 3.7 \mathrm{~kg}$ 、病理診断は myxoid liposarcomaであっ た。経過良好で術後14日目に退院。現在再発を認めていない。

32 副腎腫瘍と鑑別困難であった後腹膜 chronic expanding hematoma $(\mathrm{CEH})$ の 1 例

釧路赤十字病院外科

藤井康矢、金古裕之、安孫子剛大、三井 潤、三栖賢次郎、猪俣 斉、近江 亮

【症例】77歳男性。持続する腰痛のため他院を受診、腹部CTに て左副腎腫瘍を指摘される。EUS-FNAを含めた各種精査を施行 されるが診断つかず経過観察となっていたが、その後も腰痛が持 続するため断続的な発熱や左側腹部〜腰背部痛の症状続くため精 查目的に当院内科紹介、入院精查となった。入院時の腹部 CTで は左副腎に一致して $75 \mathrm{~mm}$ 大の被膜を有する高濃度の腫瘤像を認 めた。腹部 MRIでは内部構造不均一、中心部 T 1 強調で high、 $\mathrm{T}$ 2 強調で無信号であった。副腎腫瘍の他に副腎結核、副腎血腫、 内臟動脈瘤なども鑑別疾患として考えられたが、経時的に増大傾 向を認めたうえ、腰背部痛の増強や断続的な発熱などの症状も出 現してきたため、手術適応と判断した。【手術】開腹で施行。手 術所見では後腹膜の左腎と膵体部、左副腎との間に挟まるような 形でソフトボール大の表面平滑な腫瘍が局在していた。周囲臓器 との炎症性の癒着を認めたが浸潤傾向はなく、腫瘍摘出術が施行 可能であった。病理所見ではchronic expanding hematoma (CEH) との所見であった。術後は腰背部痛や発熱などの臨床症 状は消失し、経過良好にて退院となった。【考察】Chronic expanding hematoma $(\mathrm{CEH})$ は1ヶ月以上かけて徐々に増大する 血腫で、1980年にReidらが提唱した疾患である。発生機序は明 らかではなく、皮下などの軟部組織や胸腔内の他、後腹膜など様々 な部位の報告例がある。画像診断は困難な場合が多く、経過観察 中に増大傾向を示すという臨床経過や、痛みなどを伴うことから 外科的切除の適応となる場合が多い。若干の文献的考察を交えて 報告する。
33 囊胞状を呈した乳腺化生癌の 1 例 旭川医科大学外科学講座呼吸器乳腺外科

岡崎 智、安田俊輔、高橋奈七、石橋 佳、林 諭史、北田正博 乳腺化生癌は比較的稀な組織型であり、進行が速い症例では、内 部組織壊死による囊胞状変化を呈する事もある。囊胞内乳癌の形 状を呈した乳腺扁平上皮癌の一例を経験した。症例は83歳女性、 右 $\mathrm{D}$ 領域に $25 \mathrm{~mm}$ 大の乳房腫瘤を主訴に受診した。マンモグラフ イーはカテゴリーC-4 の腫瘤影、超音波検查では辺縁がやや不 整な囊胞内に乳頭状病変を認めた。血性内溶液であり、細胞診は 悪性疑い（SCC疑い）であった。乳房部分切除を行い、永久標 本で扁平上皮癌、T 2、Grade III、ki-67 48\%, Triple negative typeの診断となった。多房性の囊胞内腫瘤で、内面に大小不同、 多型の異形扁平上皮が増殖している像であった。囊胞周囲への乳 管内進展も認めた。二期的に腋窩手術を行い転移陰性であった。 現在、放射線照射を行い、経口抗癌剂内服中である。本病態に関 し、文献的考察を加え報告する。

34 閉経前ホルモン受容体陽性乳癌に対するLH-RH agonist追加について

札棍ことに乳腺クリニック1、札幌医科大学医学部公衆衛生 ${ }^{2}$

増岡秀次 ${ }^{1}$ 、三神俊彦 1 、下川原出 ${ }^{1}$ 、浅石和昭 ${ }^{1}$ 、森 満 ${ }^{2}$

【目的】2つの大規模第 III 相臨床試験SOFT 試験と TEXT 試験の 結果が報告され、LH-RH agonistのより有効な使い方が示唆され た。すべての患者にLH-RH agonistの併用は必要ではなく、低 リスクの患者は TAM 単独で十分な再発抑制効果が期待できる。 化学療法の追加を検討するような患者には、TAMへのLH-RH agonistの併用が必要である。LH-RH agonistの期間は 5 年が推 奨される。2013年のガイドラインではTAM 単独投与が標準治療 とされた（推奨グレードA）。一方LH-RH agonistと TAMの併 用は行っても良いとされた（推奨グレードC）。LH-RH agonist の追加効果を検討した。【対象および方法】当院で手術を施行し た非浸潤癌、両側乳癌、StageIV、術前化学療法施行例を除く閉 経前ホルモン受容体陽性乳癌1,004例を後方視的な解析の対象と した。Tamoxifenは387例に、goserelin は374例に、tamoxifen と goserelinの併用は243例に施行された。予後はKaplan-Meier 法 にて求め、検定はLogrank（Mantel-Cox）を用いた。【結果およ び考察】平均観察期間は9.58年である。リンパ節転移陰性例では 3 群間にDFS, OSともに有意差を認めなかった。しかしリンパ 節転移陽性例では、DFSにおいて tamoxifen と goserelinの併用

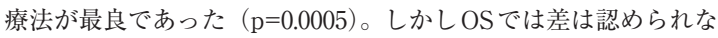
かった $(\mathrm{p}=\mathrm{n} . \mathrm{s})$ 。またgoserelinによる主な副作用は熱感 (hot flushes）で、投与回数が進むと関節痛、手のこわばりなど認め られたが投与中止となるような症例はなかった。Goserelinの投 与期間の検討では、初期は 2 年投与が最近は 3 年投与が多い。 Goserelinの追加は若年者、リンパ節転移陽性例、化学療法施行 例に多い。LH-RH agonistは 5 年投与が勧められると考えられる が今後も検討を要する。

35 当科における20歳代で発症した乳癌症例の検討 札幌医科大学消化器 · 総合、乳腺 $\cdot$ 内分泌外科学講座 里見蕗乃

【はじめに】一般的に、若年性乳癌はER陰性症例が多く予後不 良といわれている。さらに若年性乳癌の中でも20歳代での発症は 乳癌全体の $0.5 \%$ 前後と言われており、非常に少数である。今回 われわれは当科において20歳代で乳癌と診断し手術を施行した症 
例の臨床病理組織学的因子の検討を行った。【対象】2004年 1 月 〜2015年11月までに当科にて手術を施行した原発性乳癌症例1097 例中、発症年齢が 20 歳代の症例は 8 例 $(0.7 \%)$ であった。いず れの症例も妊娠期あるいは授乳期ではなく、未婚で出産歴なしで あった。【結果】発見契機はすべて自己発見 (平均腫瘍径 $2.1 \mathrm{~cm}$ ) であり、検診発見例はなかった。診断時の平均年齢は26.5歳 $(23$ 歳〜29歳) であり、病期は 0 が 1 例、I が 4 例、II A が 2 例、III $\mathrm{B}$ が 1 例であった。術式は乳房温存術が 5 例、乳房切除術が 3 例 であり、組織型はDCISが 1 例、乳頭腺管癌が 4 例、充実腺管癌 が 1 例、硬癌が 1 例、粘液癌が 1 例であった。 8 例全てが ER 陽 性であり、そのうち HER 2 陽性は 1 例のみであった。腋䆚リン パ節転移陽性は 8 例中 1 例に認められた。術後療法として化学療 法が 3 例に施行され、内分泌療法は全例に施行された。病期 II A の 1 例が術後 18 ケ月で肝転移を認め、術後 70 ケ月で死亡、病期 I の 1 例が術後 40 ケ月で局所再発を認め、残存乳房切除術を施行さ れた。残り 6 例中 5 例は現在も無再発生存中（観察期間中央值； 126r月）であるが、1 例は外来follow から外れ、転帰不明である。 【考察】今回の検討から、20代の若年性乳癌の予後は、通常の進 行度やGradeに応じたものよりも不良である可能性が示唆され た。そのため、個々の症例に応じたオーダーメイドな治療計画を 考慮する必要があると考えられる。【結語】当科における20歳代 で発症した乳癌症例を検討した。若干の文献的考察を加えて報告 する。

36 夕モキシフェンを中止し無治療とすることにより治療 効果が得られた ER 陽性転移乳癌の 1 例

北海道大学病院乳腺外科

萩尾加奈子、押野智博、笠原里紗、奈良美也子、柏倉さゆり、郭 家志、石田直子、馬場 基、山下啓子

【はじめに】選択的エストロゲン受容体モジュレーター（SERM） であるタモキシフェン（TAM）は、エストロゲンのエストロゲ ン受容体（ER）との結合を競合阻害することでエストロゲン作 用を抑制する。転移・再発乳癌に扔ける内分泌療法薬の基本的な 使い方は、作用機序の異なる薬の順次単独投与であるが、内分泌 療法耐性例に対し休薬することで一定の治療効果を得られること が報告されている。今回、ER陽性転移乳癌の内分泌療法として TAMを投与した症例において、TAM 耐性となった時点でTAM を中止することにより治療効果が得られた症例を経験したので報 告する。【症例】69歳女性。右乳房しこりを自覚し受診、針生検 の結果ER、PgR陽性、HER 2 陰性乳癌であった。右乳癌 Stage IV (多発リンパ節転移、胸膜転移) の診断となりアロマターゼ 阻害薬（レトロゾール、アナストロゾール）にて治療していたが、 1 年後原発巣増大のため $\mathrm{TAM}$ 一変更した。 1 年後再度原発巣増 大したためTAMを中止し無治療としたところ、その後約 6 ヶ月 間腫瘍縮小を認めた。原発巣は縮小傾向であったが、肝転移と一 部リンパ節増大を認めたため、現在はアロマターゼ阻害薬（エキ セメスタン）を開始している。【考察】本症例はTAM内服後、 一旦は反応するものの、一定期間をおいて治療効果がなくなった ため獲得耐性であると考えられる。TAMを中止して無治療にす ることにより腫瘍縮小や一定期間の増悪抑制が認められたことか ら、TAMがエストロゲン作用を示してTAM 耐性となったと考 えられる。TAM 耐性の乳癌に対して次の内分泌療法を考慮する 際、通常、他の種類の内分泌療法剤を選択することが多いが、 TAMのエストロゲン作用により TAM 依存性に進行するように なったと考えられる場合は、TAMを中止して無治療とすること も一つの選択肢であると考えられた。
37 コントロール困難な Air leakに対して胸膜テント変法 を施行した 1 例

札幌医科大学呼吸器外科

三品泰二郎、宮島正博、渡辺 敦

慢性膿胸に対する外科的治療として多くの術式が施行されてい る。今回肺膿瘍術後の遷延する肺ろうによる慢性膿胸に対して壁 側胸膜の骨膜外剥離を行い、死腔の閉鎖を行った。症例は72歳男 性。既往歴) COPD、膵炎（ステロイド内服）。契煙歴：20本／ dayx30年。現病歴) 肺癌疑いでに右中葉部分切除を施行。病理 結果で肺化膿症の診断。術後 3 か月間気瘦持続し、自己血パッチ を 3 回、気管支充填術を total 4 回、肺ろう閉鎖術を 3 回施行。 手術）初回手術で右中葉切除と右上葉部分切除を施行。steroid 内服のため、肺部分切除ステープルライン、縫合閉鎖部位の複数 個所からのリークを認めた。経過から air leakをコントロールす るのが困難と判断し、胸膜テント変法を選択。メジャーなリーク 部位を縫合閉鎖し、壁側胸膜を骨膜外で剥離、壁側胸膜と臓側胸 膜の表面の癒合させた。術後ドレーンチューブを胸腔内に留置し 持続吸引により陰圧をかけることで癒合を維持、リークの減少を 認めている。若干の文献的考察を含めて報告する。

\section{8 術前診断が困難であった炎症性偽腫瘍の 1 例}

帯広厚生病院外科

武藤 潤、大竹節之、山本博之、加藤航平、山村喜之、市之川正 臣、吉岡達也、村川力彦、大野耕一

症例は56歳男性。発熱と咳嗽を主訴に当院内科を受診。肺炎と診 断され、抗生剂治療を行ったが、症状や画像所見の改善を認めな いためEBUS-GS-TBBを施行した。病理組織診では腺癌の可能 性も示唆されたため、右上葉切除術を施行した。術中迅速診断で は炎症性偽腫瘍と診断され、郭清は行わず手術を終了した。術後 経過は良好で発熱や咳嗽などの症状も消失した。炎症性偽腫瘍は、 限局性、孤立性で非腫瘍性の性格をとり、組織学的には膠原線維 および炎症細胞、間葉系細胞が混じり合っている病変をいう。頻 度は外科切除された肺腫瘍の $0.04 \%$ との報告もあり、稀な疾患で、 感染の関与が指摘されている。本症例も発熱を契機に発症してお り、感染の関与が示唆されたが起因菌は同定できなかった。術前 診断が困難で肺癌が疑われている症例も多く、診断と治療を兼ね ての外科的切除が第一選択である。切除不能症例はステロイドも 選択されるが、感染の関与も考慮すると、慎重な使用が必要であ る。

39 胸壁原発性悪性顆粒細胞腫の 1 例 A case of malignant granular cell tumor in chest wall

手稲渓仁会病院外科

篠原良仁、加藤弘明、武内慎太郎、寺村紘一、今村清隆、田畑佑 希子、阿部 大、早馬 聡、田本英司、高田 実、木ノ下義宏、 安保義恭、中村文隆、成田吉明、樫村暢一

原発性顆粒細胞腫 granular cell tumor は稀な軟部組織腫瘍であ る。そのうち、悪性の顆粒細胞腫は顆粒細胞腫の $1-2 \%$ といわ れている。また、悪性顆粒細胞腫の治療法は現在のところ確立し ておらず、外科的切除による根治術が第一とされている。今回、 われわれは胸壁原発の悪性顆粒細胞腫の 1 例を経験したので、若 干の文献的考察を含めて報告する。

症例は62歳女性で、2013年 7 月に前医で左胁骨弓の腫瘤を指摘さ れ当科紹介となった。診察上、左肋骨弓遠位部に約 $5 \mathrm{~cm}$ の可動 性のある弾性硬の腫瘤を触知した。単純 CTで、左第 9 肋軟骨上 
の筋膜下に約 $4 \mathrm{~cm}$ 大の腫瘤を認めた。MRIでは一部胁骨胸膜と の癒着も疑われた。経皮的針生検を施行し、granular cell tumor が疑われたが、良悪性の判断を含め、針生検では確定診断に至ら なかった。 8 月に手術施行。腫瘍は外腹斜筋に存在し、肋軟骨と の関連は無かった。 $1 \mathrm{~cm}$ の margin を確保し腫瘍を摘出し、術後 4 日目に退院となった。その後の永久標本で、malignant granular cellの診断となった。病理結果で、内側断端の一部が腫瘍と 近接していたことから同年 9 月に追加切除を行った。術後 4 日目 に退院となり、その後の病理結果でも腫瘍の遺残は認めなかった。 現在術後 2 年 6 力月経過したが、再発無く経過している。

\section{0 特発性縦隔気腫の 6 例}

勤医協中央病院呼吸器センター外科

栃窪 藍、川原洋一郎、田尾嘉浩、林 浩三、松毛眞一

縦隔気腫は縦隔内に空気が貯留した状態をいう。外傷や手術など に伴って生じることが多いが, 基礎疾患のない健康な例に発症し た縦隔気腫を特発性縦隔気腫と呼び, 比較的まれな疾患とされる. 2008年から2016年までに入院加療した特発性縦隔気腫 6 症例を報 告する. 男性 5 例, 女性 1 例で, 平均年齢は22.8歳であった。誘 引を認めたのは 4 例で, その内容は歌唱, スポーツ, 上気道炎, 嘔吐であった。全例になんらかの自覚症状を認めた。皮下気腫を 認めたのは 1 例であった. 全例胸部 X線写真と胸部 CT 写真にて 診断した. 1 例で, 左舌区および左下葉の気管支肺動脈に沿う可 逆的な気腫像を認め, Macklinの仮説が示唆された. 1 例のみ抗 生剂を投与したが, 他は安静療法のみで改善し, 外科的処置を要 した症例は無かった. 外来経過観察時点では全例に再発を認めな かった.

\section{1}

筋ジストロフィーに合併した気管支閉塞・気道出血の

1 例

国立病院機構函館病院外科

藤原 晶、城崎友秀、岡村国茂、山吹 匠、小室一輝、岩代 望、 大原正範

【症例】40歳代男性. 6 歳時より Duchenne型筋ジストロフィー で前医入院中. 血性痰と右中下葉の無気肺を認めたため精查加療 目的で当院へ転院. 気管支鏡検查では右主気管支の壁外性圧迫を 認め, 胸部 CTでは強い側弯と胸郭変形を認めた. 以上から, 椎 体に圧迫された右主気管支の粘膜が擦れて出血を来したと考え た. 止血が得られていたため経過観察の方針となり前医へ転院し た.【考察】Duchenne型筋ジストロフィーはX染色体劣性遺伝 性疾患で, 5-6歳以降徐々に筋力低下が進行し, 歩行機能消失, 呼吸筋力低下, 側弯, 心筋症等が出現する。 20歳代で呼吸不全や 心不全で死亡することが多いが包括的医療の進歩により長期生存 例も増加している. 脊椎変形は進行性で側弯・後弯が生じ回旋も 伴う. 本症例はこの脊椎変形が気道閉塞・無気肺および出血の原 因となった，大量喀血や無気肺による炎症所見が遷延する場合は 手術やステント留置も検討する予定である.

42 術前に高分化腺癌との合併を疑った気管支結石症の 1

切除例

札幌南三条病院呼吸器外科

八木優樹、加地苗人、長 靖、椎名伸行

気管支結石症は, 気管支沿内に石灰化物が存在する状態と定義さ れ, 比較的稀な疾患である。【症例】70歳代女性。X年 8 月に高 血圧経過観察中の近医で胸部異常侩影を指摘された。胸部 CTで
右下葉 S 9 bに $16 \times 16 \times 14 \mathrm{~mm}$ 大の pure GGO 病変を認め, その 内部に $6 \times 3 \mathrm{~mm}$ 大の濃度上昇している結節を認めた。 PET-CT においても GGO病変に一致してSUV-max 2.8の有意集積を認め た，気管支境生検で悪性所見はえられなかったが，悪性腫瘍を否 定できず外科的切除の方針となった。気管支結石症とそれに合併 する高分化腺癌を疑い，手術を施行。【手術】胸腔鏡下に右下葉 切除+ND 1 を施行した。手術時間 2 時間30分。出血量少量。【術 後経過】術後, 大きな合併症なく13日目に自宅退院とした。病理】 永久標本で気管支結石症と判明し，その末梢の GGO 病変となっ ていた筒所に悪性所見は認めなかった。比較的稀な気管支結石症 の1例を経験したため、文献的考察とともに報告する。

43 経腟式子宮全摘後に生じた左子宮広間膜ヘルニアの 1 例

市立函館病院消化器外科

長瀬勇人、笠島浩行、加藤紘一、佐藤利行、久留島徹大、砂原正 男、鈴木伸作、中西一彰、木村 純

症例は70歳女性。開腹歴はないが経腟式子宮全摘術の既往がある。 肺癌に対する化学療法の副作用のため当院呼吸器内科入院中であ ったが、間欠的な腹痛・嘔吐が出現し、腸閉塞と診断され当科へ 紹介となった。CTでは左下腹部に閉塞機転が認められたが、腸 管壊死を疑う所見がないため、イレウスチューブによる保存的治 療を行った。イレウスチューブ挿入 6 日後に腹部所見の増悪を認 めたためCTを再検し、ダグラス窩・左後腹膜に膿瘍形成が認め られた。腸管壊死を疑い、緊急手術を行ったところ左子宮広間膜 に 1 横指程度の裂孔が存在し、回腸が陥頓していた。陥頓した腸 管は壊死し、一部後腹膜へ穿通していた。壊死腸管を切除し、ダ グラス窩・左後腹膜に貯留した膿崵の洗浄・ドレナージを行い、 広間膜の裂孔を縫合閉鎖した。子宮広間膜へルニアは非常に稀な 疾患ではあるが、開腹歴のない女性で骨盤内に閉塞機転が認めら れる症例では念頭に置くべき疾患であると考えられた。

44 両側閉鎖孔へルニアに対してメッシュプラグを用いて 腹腔鏡下修復術を施行した 1 例

日本海員掖済会小樽掖済会病院外科 1 、札幌医科大学消化器·総合、 乳腺 $\cdot$ 内分泌外科学講座 ${ }^{2}$

及能拓朗 1,2 、大野敬祐 1.2 、今野 愛1,2、高原文治 1 、三浦 亮 1,2 、佐々 木一晃 ${ }^{1,2}$ 、竹政伊知朗 2

【症例】78歳女性。左下腹部痛㧍よび左下肢痛を主訴に前医受診。 CTで左閉鎖孔へルニア嵌頓によるイレウスの診断で当院紹介と なった。搬送後、症状は軽快しており、当院造影 CTでは腸管の 嵌頓は自然に整復されていた。再発の可能性を考慮し、待機的に 修復術を施行した。【手術】TAPPに準じてポートを挿入した。 左右閉鎖孔ヘルニアを確認でき、左側は大網の脱出を認め、腹㬶 内へ還納した。腹腔鏡下にメッシュプラグをヘルニア門よりへル ニア囊内へ直接抻入、ヘルニア門の周囲腹膜を巾着縫合により縫 縮することで修復した。【経過】術後 2 か月経過したが、再発は 認めていない。【考察】閉鎖孔ヘルニアの修復術は様々あり、最 近では腹腔鏡下手術、特にメッシュプラグもしくはシートを使用 した報告例が散見される。本症例ではより簡便な方法としてメッ シュプラグをへルニア門へ直接挿入して閉鎖した。再発を含めた 合併症に対して長期的な観察が必要であるが、閉鎖孔へルニアは 高齢者に多く、治療の低侵襲化を考慮すると、本症例のような簡 便な修復法は選択肢の一つになりえるものと考えられた。 
45 閉鎖孔ヘルニア術後に大腿部膿痬を併発した 1 例 八雲総合病院外科

齋藤博紀、阿部島滋樹、畠山純一

症例は94歳女性。心窩部痛を主訴に当院内科を受診。腸閉塞の診 断で入院し保存的加療を開始した。入院 2 日目に嘔気、右下肢痛 を認め当科に紹介された。CT検查にて右閉鎖孔ヘルニア嵌頓と 診断し、緊急手術を施行した。閉鎖孔に嵌頓していた回腸を整復 したところ、穿孔部から腸液が腹腔内に漏出した。ヘルニア門、 ヘルニア囊は処置せずに小腸部分切除、洗浄ドレナージを施行し た。術後26日目に発熱㧍よび右大腿部痛が出現し、CT検查にて 閉鎖孔から右大腿部に進展する膿瘍形成を認め、右大腿部を切開 し排膿した。さらに膿瘍が大腿深部に波及した為、切開ドレナー ジの追加を要した。その後、膿瘍は徐々に消退し、術後62日目に 退院となった。閉鎖孔へルニア術後に炎症反応の遷延や再燃を認 めた場合は骨盤から大腿に波及する深部膿瘍を合併する可能性が あり、その際には十分なドレナージ処置が肝要である。

\section{6 子宮を内容物とする鼠径部ヘルニア嵌頓の一例}

遠軽厚生病院外科

栗山直也、石井大介、北 健吾、後藤順一、橋本道紀、稲葉 聡、 矢吹英彦

症例は80歳女性。主訴は左鼠径部膨隆。既往に 4 回の左鼠径へル ニア手術があるが 3 回分の詳細は不明。最終手術は 2008 年 3 月に 当科でKugel法を施行した。2016年 2 月中旬、左鼠径部膨隆を自 覚し 3 日後に近医受診。左鼠径ヘルニア嵌頓と診断されたが整復 できず、当科を紹介された。造影 CTで、子宮を内容とする鼠径 ヘルニア嵌頓が疑われたため、緊急手術とした。方針は腹腔鏡下 で行い、整復できなければ前方アプローチ、開腹の可能性も考慮 とした。腹腔鏡にて恥骨上からの子宮脱出を確認したが、子宮を 率引するも戻らず、腹腔鏡補助下前方アプローチへ移行した。嵌 頓整復し、子宮に壊死がないことを確認した後、ヘルニア門に Mesh plug を抻入、固定しonlay パッチをおいて手術終了とした。 術後は合併症なく、リハビリを施行後、術後16日で退院となった。 鼠径部へルニア子宮嵌頓は稀な疾患であり報告例も少ない。文献 的考察も踏まえ報告する。

47 前立腺全摘術後の鼠径ヘルニアに対する腹腔鏡下鼠径 ヘルニア根治術（TAPP）の適応と問題点

市立旭川病院外科

村上慶洋、宮坂 衛、阿部紘丈、福永亮朗、笹村裕二、武山 聡、 沼田昭彦、子野日政昭

前立腺全摘術後の鼠径ヘルニアに対する腹腔鏡下鼠径ヘルニア根 治術の適応、手術方法については、本術式が普及してきた現在で も、定まった見解はない，当科では2013.2月から2016.5月までに 前立腺全摘術後の鼠径ヘルニアに対し、12例13病変にTAPPを 施行した。全例、初発例で用いているParietex Anatomical Meshでの修復が可能で、腹膜の閉鎖も可能であり、TAPPでの 完遂が可能であった．現在の処、術後合併症や再発を認めていな い. 前立腺全摘術後では特に内側・恥骨側の癒着、瘕痕化の為、 剥離困難な症例が多く、膀胱損傷等の可能性もある事. 一方で内 側の㾮痕化の為そのほとんどが外鼠径へルニアとして発症するた め、Mesh Plug法やTAPPの場合でも癒着防止フィルム付きの Meshを用い内側は剥離を行わない方法が望ましい等の報告があ る.しかしながら今回、両側内鼠径ヘルニアとして発症した症例 を経験し、腹腔鏡での䛦断と症例に合わせた剥離修復が必要と考
えられたため、本術式の手技、及び適応と問題点につき考察し報 告する。

48 腹胿鏡手術を行った横隔膜傍裂孔ヘルニアの 1 例 北見赤十字病院外科

大川裕貴、池田淳一、新関浩人、山口晃司、松永明宏、宮谷内健 吾、新田健雄、廣瀬和幸、羽根佑真、北上英彦

症例は64歳, 女性. 1 力月前より食直後の嘔吐, 心窩部痛があり, 当院を受診された. 精查の結果, 横隔膜ヘルニアと診断されたが, ヘルニア門の局在は正確に断定できなかった. 経口摂取不能のた め手術適応と判断した。手術は腹腔鏡下に行った。手術所見では 胃底部から胃体部が食道裂孔方向に陥入しており，傍食道ヘルニ アと考えた。剥離を進めると食道裂孔とヘルニア門の間に左横隔 膜脚が介在することが判明し傍裂孔ヘルニアの診断となった。 ルニア門である左脚を背側より縫合し，U字型メッシュを使用し た. Toupet法で噴門形成を行い手術は終了した。術後経過は良 好で 9 日目に退院した。今回検索した範囲内では本疾患の本邦報 告例は31例と稀であり術前診断も困難な場合が多い. しかし本疾 患を念頭に置いた上で改めて術前 CT 読影すると横隔膜の介在 を確認できたため, 術前に診断することも可能であったと考えた. 以上，若干の文献的考察を含めて報告する.

49 肝pseudolymphomaの 3 切除例

$\mathrm{JA}$ 北海道厚生連札幌厚生病院外科1、同病理診断科 ${ }^{2}$

金野 匠1 、柿坂達彦1、田原宗徳1、石津寛之 1 高橋昌宏1、岩口 佳史 $2 、$ 市原 真 2 後藤田裕子2、村岡俊二 ${ }^{2}$

症例 1 は65歳女性で、S 状結腸癌の精查で肝S 6 に $4 \mathrm{~mm}$ 大の腫 瘍を認め、肝転移の術前診断で $\mathrm{X}$ 年 7 月に腹腔鏡下 $\mathrm{S}$ 状結腸切除 および肝 S 6 部分切除を行った。症例 2 は81歳女性で、NASH肝 硬変を当院消化器科でフォローされていたが、CTでS 8 に $8 \mathrm{~mm}$ の過形成結節と、S 8 に $8 \mathrm{~mm} 、 \mathrm{~S} 6$ に $9 \mathrm{~mm} 、 \mathrm{~S} 3$ に $5 \mathrm{~mm}$ の腫 瘍を指摘され、S 8 の過形成結節と S $8 、 S 3$ の腫瘍に対して RFAを施行した。S6の腫瘍については、後区域のグリソンに接 していたため RFA を施行できず、 $\mathrm{X}$ 年10月に肝 $\mathrm{S} 6$ 部分切除を行 った。症例 3 は 57 歳女性で、自己免疫性肝炎として当院消化器科 でフォローされていたが、X年 7 月の超音波検查で肝 S 3 に 8 $\mathrm{mm}$ の腫瘍を指摘され、精査の結果、肝細胞癌の術前診断となり、 $\mathrm{X}$ 年10月に腹腔鏡下肝 S 3 部分切除を行った。

切除肝の病理組織学的所見では、3例とも小型リンパ球の密な浸 潤やリンパ濾胞、小型の類上皮細胞肉芽種を認めた。リンパ球に 異型はなく、リンパ球マーカーでの検索では monoclonal な腫瘍 性リンパ球の増殖を認めないことから、pseudolymphomaの診断 となった。

消化管、眼窩、肺、皮虐などでは pseudolymphomaが発生する 頻度は高いが、今回、稀である肝pseudolymphomaの切除例を 3 例経験したので、病理学的所見を中心に文献的考察を加えて報 告する。 
50 境界病変と診断された肝腫瘍に対する腹胿鏡下肝切除 術の検討

北海道大学消化器外科 I

脇坂和貴、神山俊哉、横尾英樹、折茂達也、若山顕治、島田慎吾、 永生高広、蒲池浩文、武富紹信

目的:腹腔鏡下肝切除術は低侵襲性と整容性に優れた術式であり、 当科ではこれまで114例施行してきた。当科における術前に境界 病変と診断された症例の腹腔鏡下肝切除術について検討する。対 象と方法 : 2001年 1 月から2016年 4 月までに当科で施行した腹脉 鏡下肝切除術114例のうち、術前に境界病変と診断された症例は 6 例であった。手術時間、出血量、合併症、術後在院期間などに ついて検討した。結果：境界病変と診断された 6 例の術前診断は 肝細胞癌疑いが 4 例、その他が 2 例であった。病理診断はbile duct cyst 1 例、肝血管腫 1 例、肝血管筋脂肪腫 2 例、限局性結 節性過形成 1 例、高分化型肝細胞癌 1 例であった。平均手術時間 は241分であり出血量は少量であった。術後合併症の発生はなく、 平均術後在院日数は6.6日であった。結語：術後経過は良好であ り早期に退院することが可能であった。境界病変に対しては診断 と治療の観点において腹胿鏡下肝切除術は有用であると考えられ た。

51 肝エキノコックス症を併発した肝門部領域胆管癌の 1 切除例

北海道大学医学研究科消化器外科 II

植村慧子、野路武寛、梅本一史、斉藤博紀、田中公貴、中西喜嗣、 浅野賢道、中村 透、土川貴裕、岡村圭祐、七戸俊明、平野 聡 80歳代男性。他院にて出血を伴う胃癌に対し幽門側胃切除を施行 された。術前に軽度の肝内胆管の拡張を指摘されていたが、経過 観察されていた。胃癌術後 9 ケ月目に施行したCT検查にて肝左 葉の著明な肝内胆管の拡張を指摘され、血液生化学的検查結果で は胆道系䤏素および血清 CEAの上昇を認めた。腹部 CT 検査で は肝S 4 を中心とする境界不明瞭な腫瘤性病変と、左右肝管合流 部から左肝管に壁肥厚と内腔の狭小化を認めた。その他、肝 S 6 に $9 \mathrm{~mm}$ 大の低吸収域を認めたが、造影超音波所見から肝膿瘍と 診断した。以上の所見より肝門部領域胆管癌と診断し、左葉尾状 葉 ·胆管切除、S 6 部分切除 (切除生検) を行った。術後病理組 織学的診断で左肝管を中心に全周性の結節浸潤型の壁肥厚を認 め、肝門部領域胆管癌と診断した。また、S 6 およびS 4 の主腫 瘍に近接する肝実質内に原頭節を含むクチクラ層を認め、エキノ コックス (多包虫) 症の併発と診断した。

\section{2 複数の微小肝転移を伴う胆囊神経内分泌癌の 1 例} 北海道消化器科病院外科

桑谷俊彦、楢崎 肇、中山智英、福島正之、田中栄一、藤田美芳、 森田高行

症例は76歳女性. 心窩部痛・背部痛を主訴に近医受診し, 胆石症 の疑いで当院内科紹介となった，画像所見より胆囊内に充満する 血流を伴う腫瘤性病変を認め, 肝S 4 - 胃・横行結腸への浸潤が 疑われた. 病理診断は得ず, 胆囊癌の疑いで手術の方針となった。 胆囊癌とすると Gbf T 4 a (胃, 大腸) N 0 M 0 Stage IV a の術前 診断で, 手術は胆囊管断端の陰性を確認した後に, 胆囊摘出術, 胆囊床切除術, D 2 郭清, 胃 ・ 横行結腸合併切除を施行した。病 理組織診断はGfbn充満型 T $3 \mathrm{a}$ (漿膜・結腸）N 1 （12c 陽性） M 1 (肝) Stage IV bであった. 腫瘍細胞は形態学的にロゼット 様配列や縦列状浸潤を認める神経内分泌癌（NEC）の特徵を示
す領域と，異型腺管を形成する高〜中分化腺癌の特徵を示す領域 を認めた。両組織型はCytokeratin（AE $1 / \mathrm{AE} 3$ ), CK 7 陽性で あったが，NEC領域でのみ chromogranin A, synaptophsinが陽 性であった，腺癌領域は $30 \%$ 未満であり，WHO（2010）の混合 型線神経内分泌癌（MANEC）の定義は満たさず，胆囊神経内分 泌癌の診断であった，肝の浸潤と考えられた病変は複数の微小な 転移であり，転移リンパ節ともにNECの組織であった。術後 cisplatin+irinotecanによる化学療法治療中であるが, 術後 7 か月 無再発生存中である。

胆囊神経内分泌癌は比較的稀で, リンパ節転移や肝転移をきたし やすく，予後不良な疾患である。肝転移を伴うものは手術非適応 となるが, 今回我々は複数の微小肝転移を伴う胆囊神経内分泌癌 の手術症例を経験したので報告する。

53 肝転移を有する胆囊癌肉腫の 1 切除例

手稲渓仁会病院外科 1 、同病理診断科 2

今村清隆1、安保義恭1 篠原良仁 1 横山新一郎1、伊橋卓文1、西 智史 1 、吉見泰典 1 、水沼謙一1、武内慎太郎 1 、寺村紘一 1 、早馬 聡 1 、 田本英司1 、高田 実1、木ノ下義宏1、中村文隆1、樫村暢一1、大 森優子 2 、篠原敏也 ${ }^{2}$

症例は72歳男性. 高血圧症で通院治療中に, 肝機能障害, 体重減 少を認め, 精查のため当院を紹介された．腹部 CTで胆囊腫瘍が 疑われ，腫瘍は胆囊に限局し周囲組織への浸潤を認めなかった。 壊死傾向が強く肉腫を疑う所見であった．胆囊䅡部のブラシ細胞 診の結果， spindle cell tumorが認められた。また肝S 8 にも腫瘤 像がみられ, 肝生検で癌肉腫 carcinosarcoma と診断され肝転移 と考えられた。転移腫瘤は前区域グリソンに接しており，切除に は肝右葉切除が必要な所見であった。進行度StageIVBの胆囊癌 と診断したが, 癌肉腫に対しては有効な抗癌剤治療が確立されて いないこと, 本症例においては安全な腫瘍切除が可能と判断し手 術の方針とした.

診查腹腔鏡にて腹膜播種や肝表面の転移を認めなかったので，門 脈右枝塞栓術（TIPE）を施行した．TIPE後20日目に切除術を施 行した，手術はリンパ節 $12 \mathrm{p} ， 12 \mathrm{~b} ， 13 \mathrm{a}$ 廓清ののち，胆囊管を合 流部で切離して迅速病理検查提出した．胆囊管断端は癌陰性であ り，総胆管温存のうえ肝右葉切除を施行した。

肉眼的に胆囊内腔に充満する腫瘍を認め, 組織学的には胆囊䅡部 原発の癌肉腫 (carcinosarcoma) の診断で, Gn, 50x45x35mm, pT 2, med, INFa, ly 0, v 1, ne 0, pN 0, M 1 (Hep : 2 個), StageIVB, 断端陰性の病理診断であった。術後補助化学療法は 希望されず外来定期通院中であるが, 術後 1 年 3 个月無再発生存 中である.

胆囊癌肉腫は稀な疾患で予後不良とされるが, 一方で切除後の長 期生存例もみられる. 今回, 文献的考察も含め報告する.

54 胆囊出血を契機に発見された膵胆管合流異常を伴う胆 囊癌の 1 例

斗南病院外科

河合典子、山本和幸、森 大樹、花城清俊、佐藤大介、才川大介、 鈴木善法、川田将也、川原田陽、北城秀司、大久保哲之、奥芝俊 一

症例は 30 代の女性で, 上腹部痛を主訴に当院へ救急搬送となった。 造影 CTで胆囊内腔に充満する腫瘤性病変と, その内部に $\mathrm{ex}-$ travasation と考えられる領域を認めた。 EUSでも胆囊内部に凝 血塊を認め, 胆囊腫瘍からの出血が考えられた、MRCPでは軽 度の胆管拡張を伴った膵・胆管合流異常を認めた。膵・胆管合流 
異常を伴った胆囊癌および胆囊内出血の疑いの診断で拡大胆囊摘 出術, 肝外胆管切除術, リンパ節郭清を施行した。摘出標本の肉 眼所見では胆囊の内腔に向かって乳頭状に増殖する $78 \times 65 \mathrm{~mm}$ 大 の病変で, 病理組織学的に papillary-expanding typeの胆囊癌, pT 1 bN 0 Stage I と診断された.

胆囊癌からの出血は稀であり，本邦で膵・胆管合流異常を伴い胆 道出血を来した胆囊癌の報告は検索し得た限り過去に 1 例のみで あった．胆囊出血を契機に発見された早期胆囊癌および膵・胆管 合流異常症を経験したので, 若干の文献学的考察を加え報告する.

\section{5 術前に腸間膜由来の腫瘍が疑われた膵神経内分泌腫瘍} の 1 切除例

王子総合病院外科 1 北海道大学大学院医学研究科病理学講座分 子病理学分野 2

松本 嶺1、松井あや1、野村俊介1、真木健裕1、鯉沼潤吉1、狭間 一明 1 渡邊幹夫 1 、岩井和浩1 、大塚紀幸 2

【はじめに】非機能性膵神経内分泌腫瘍は自覚症状にそしく、大 きな腫瘤を形成するまで診断に至らない場合が少なくない。こう した症例では膵との連続性がわかりにくく、術前診断に苦慮する ことがある。腹部腫瘤を呈し、術前に腸間膜由来の腫瘍と診断し た膵神経内分泌腫瘍の症例を経験したので報告する。症例】37歳、 女性。【現病歴】避妊薬内服中、近医婦人科定期健診にて腹水䝪 留を指摘され、腹部 CTにて $12 \mathrm{~cm}$ 大の腫瘍を認めたため、精查 目的に当院紹介となった。【血液生化学検査】腫瘍マーカーでは CA125が276.1 U/mLと上昇を認めたが、CA19- 9 およびCEAは 正常範囲だった。可溶性IL-2 レセプターが5 $32 \mathrm{U} / \mathrm{mL}$ と高值だ った。画像検查】腹部超音波検查で左上腹部に分葉状で内部不 均一な $12 \times 10 \mathrm{~cm}$ の腫瘤を認めた。腫瘤内部は囊胞状に変性して いたが、辺縁にはカラードプラで豊富な血流が示された。造影 CTでは腫瘤内部は不均一に造影され、上・下腸間膜静脈の分枝 が腫瘍に分布していたため、腸間膜由来の腫瘍を疑った。腫瘤頭 側は胃および膵体尾部に接し、膵との境界は不明瞭であった。ま た、膵体部脾静脈近傍に腫大したリンパ節を認めた。PET-CT では腫瘤およびリンパ節に一致して、それぞれSUVmax 6.0、2.5 の異常集積を認めた。MRIではT 1 で一部高信号をふくむ低信 号、T 2 で低信号であった。巨大な腫瘤であること、多血性腫瘤 であることから悪性腫瘍と考え、腫瘤およびリンパ節から超音波 内視鏡下生検を施行した。いずれの検体からも接着性のそしい類 円形細胞が認められ、免疫染色より低分化型の上皮系腫瘍と診断 されたが、確定診断にはいたらなかった。【手術】開腹時に多量 の腹水貯留を認めたが、術中迅速細胞診はClass IIの診断だった。 腫瘤と膵体部は一塊となり中結腸動静脈を巻き込んでいた。膵由 来の腫瘍と判断し横行結腸間膜の合併切除を伴う尾側膵切除を行 い、D 2 郭清を併施した。【病理診断】腫瘤の最大径は $12.5 \mathrm{~cm}$ 大で、 割面は白色充実性であった。免疫染色では chromogranin Aおよ びsynaptophysinは 陽 性、gastrin、glucagon、insulin、somatostatinは明らかな陽性所見が認められず、特異的な臨床症状が 見られなかったことから非機能性膵神経内分泌腫瘍と診断され た。脾静脈内塞栓および脾動脈浸潤を伴い、高度な脈管侵襲（ly 3，v 3 ）も認められた。核分裂像 $3 / 10 \mathrm{HPF} 、 \mathrm{Ki}-67$ 陽性率 $15 \%$ であり、WHO分類ではNET G 2 であった。以上より pT 4 N 1 M 0、pStage IVa と診断した。【術後経過】術後合併症なく、術 後10日目に退院となった。【考察】本症例では画像所見より腸間 膜由来の腫瘍を疑ったが、最終的に膵内分泌腫瘍であることが判 明した。膵近傍の腫瘍では術前に膵原発の腫瘍を鑑別に含める必 要がある。
56 診断に苦慮した膵囊胞性病変の 1 例 札幌医科大学消化器・総合、乳腺・内分泌外科

河野 剛、木村康利、及能大輔、山口洋志、今村将史、目黒 誠、 水口 徹、竹政伊知朗

【背景】膵囊胞性病変の診断と治療方針の決定は時に困難である。 【症例】60代、男性。右背部痛を主訴に近医受診され、腹部 CT にて膵尾部に $2 \mathrm{~cm}$ 大の囊胞性病変を認めた為、精查加療目的に 当院紹介となった。CT, MRIにて脾臓と同様の信号を呈する $10 \mathrm{~mm}$ 大の結節が囊胞性病変と連続して認められ、膵内副脾発生 の epidermoid cystを疑ったが、EUSにて腫瘤辺縁に充実性成分 を認め、PNETの囊胞変性も疑われた。FNAを複数回行うも確 定診断には至らず、診断も兼ねて切除の方針となり、腹腔鏡下に 核出術を行った。術後の経過は良好で、術後13日目に退院した。病 理所見】囊胞周囲に副脾を認めた。囊胞の内側壁は平滑で、内部 に黄色調で槳液性の内容物を認めた。囊胞壁は一層の立法上皮で 裏打ちされ、また囊胞周囲には菲薄化した膵組織を認めており、 貯留囊胞の診断であった。今回われわれは術前診断に苦慮した膵 貯留囊胞の 1 例を経験したので、報告する。

\section{7} 十二指腸穿孔と結腸間膜断裂を伴った外傷性膵損傷の

\section{1 例}

市立釧路総合病院外科

吉田雄亮、佐藤暢人、宮崎 大、井上 玲、福田直也、飯村泰昭、 長谷川直人

症例は55歳の男性で, 交通外傷による腹部のハンドル殴打で搬送 された. CTでは膵頭部腹側に血腫を認め, 腹腔内遊離ガスや造 影剂の血管外漏出は認めなかった. 腸間膜血腫, 膵頭部挫滅を疑 い, 集中治療室で経過観察を行った. 6 時間後に撮影したCTで 腹腔内遊離ガスが出現し, 消化管穿孔の診断で緊急手術を施行し た，術中所見では十二指腸穿孔，膵鈎部断裂，膵体部挫滅，腸間 膜断裂による横行結腸壊死を認めた。 ERPで主膵管損傷のない ことを確認し, 十二指腸, 断裂膵, 右半結腸を切除し, 膵の挫滅 部と断端にドレナージを行った。術後, 膵液瘦に伴う遅発性の縫 合不全を認めたが, 既存のドレナージルートで保存的に改善し, 術後81病日に退院した。外傷性膵損傷は他藏器損傷を伴うことが 多いとされるが, 比較的まれである，今回，われわれは，外傷性 膵損傷に十二指腸, 結腸間膜損傷を伴った 1 例を経験したので若 干の文献的考察を加えて報告する.

58 膵体部温存手術を行った 1 例 北海道大学大学院医学研究科消化器外科学分野 II 梅本一史、中村 透、植村慧子、齋藤博紀、田中公貴、中西喜嗣、 浅野賢道、野路武宽、土川貴裕、岡村圭祐、平野 聡 症例は胃全摘・膵脾合併切除術の既往を持つ64歳の女性. 腹部膨 満感を主訴に前医を受診し，癒着性腸閉塞で入院となった。その 際CTにて残膵内の腫瘤影を指摘され，SMV浸潤を伴う膵頭部 癌の診断で当科紹介となった. NACRTの臨床試験に参加し S- 1 /RTを施行後，手術を施行した。手術は膵全摘を回避した門脈 合併膵頭十二指腸切除を計画した．前回手術で脾動脈は根部で切 除されていたが, 術前の血管造影で背膵動脈がSMAから分岐し ていることを確認し, 膵体部が温存可能と判断した. 実質の切離 線は術中超音波にて決定し, ICG 蛍光法で温存した残膵の血流を 確認した. 膵切除断端は陰性 (R 0 切除) であった. 術後合併症 はなく, 術後の耐糖能は内服治療で管理良好であった. 残䅴の温 
存は術後の内·外分泌機能に直接関与し, 術後のQOLを左右する. 特に胃全摘術後の場合, 膵機能の廃絶は重篤な QOL低下要素と なるため、根治性を低下させない範囲で可能な限り膵機能温存を 考虑すべきと考える。

59 局所進行膵癌における NAC-RT後の適切な SMA 後 方郭清範囲に関する検討

北海道大学病院消化器外科 $\mathrm{I}^{1}$ 、同病理部 2

永生高広 ${ }^{1} 、$ 蒲池浩文 ${ }^{1}$ 、敦賀陽介 ${ }^{1}$ 、田中友香 ${ }^{1}$ 、脇坂和貴 ${ }^{1}$ 、島田 慎吾1、若山顕治1、折茂達也1、横尾英樹1、神山俊哉1、三橋智子、 武富紹信 ${ }^{1}$

【目的】近年局所進行膵癌に対して術前化学放射線療法 (NACRT）を施行後に切除可能症例に対しては手術を行っている。上 腸間膜動脈 (SMA) 神経叢に対する NAC-RT 後の切除範囲に関 しては術中に癌の進展範囲を判断することが難しいことから切除 範囲を術前に決定して臨む必要がある。【対象と方法】2005年か ら2016年までに当科でNAC-RTを施行した38例。SMA 神経叢浸 潤に関しては診断時と NAC-RT後にCTを用いて画像評価を実 施した。SMA 神経叢の切除範囲はNAC-RT 施行前の浸潤予想範 囲とした。NAC-RT 前後の画像評価と術後病理結果を比較検討 した。【結果】NAC-RT施行38例中17例に手術を施行。全例肉眼 的 R 0 手術を実施した。病理結果はSMA 神経叢に関しては全例 断端陰性であった。Evans分類はGrade I 1 例、Grade II a 6 例、 Grade IIb 8 例、Grade III 2 例。術後再発症例は13例で再発初 発部位は肝転移 5 例、肝門部リンパ節転移 1 例、肺転移 6 例、腹 膜播種 1 例。局所再発は認めていない。【結語】SMA 神経叢の切 除範囲は診断時の画像評価に基づいて切除することで切除断端陰 性が得られる。

\section{0 門脈合併切除を要した巨大漿液性囊胞腺腫の 1 例 北海道大学大学院医学研究科消化器外科学分野 II}

渡辺一永、野路武寛、梅本一史、植村慧子、斉藤博樹、田中公貴、 中西喜嗣、浅野賢道、中村 透、土川貴裕、岡村圭祐、七戸俊明、 平野 聡

症例：70歳代女性。スクリーニングにて施行した腹部超音波検査 （US）にて膵頭部腫瘍を指摘され精査を行った。画像診断にて 8 $\times 7 \mathrm{~cm}$ 大のSCN と診断され、経過観察されていた。初回診断か ら13年後、背部痛が悪化し手術適応として紹介された。術前画像 検查では、膵頭部に $15 \mathrm{~cm} \times 14 \mathrm{~cm}$ 大の辺縁平滑で周囲との境界明 瞭な類円形の多房性腫瘍を認めた。上腸間膜静脈は狭小化してい た。

手術：腫瘍は膵・周囲腸間膜に固着していた。膵頭部の膵実質を 一部切除して、腫瘍を核出した。上腸間膜静脈 - 門脈 - 脾静脈合 流部を合併切除・端々吻合（脾静脈非再建）とした。術後膵液漏 を認めドレナージを要した。

病理結果：多房性囊胞状構造を呈し・周囲に膨張型発育を呈する 腫瘍を認めた。腫瘍細胞は淡明・好酸性細胞質に、異型のそしい 核を有し、SCN (Mixed type) と診断された。合併切除した門 脈壁には腫瘍の直接浸潤を認めないものの、門脈壁の弾性繊維は 破綻していた。
61 腹腔鏡下に切除した脾 sclerosing angiomatoid nodular transformation $の 1$ 例

王子総合病院外科 1 、北海道大学大学院医学研究科分子病理学分 野 2

細井勇人1、岩井和浩1 渡邊幹夫1 、狭間一明 1 、鯉沼潤吉 1 、松井 あや1、八木優樹1、外丸詩野 2

症例は60歳、男性。検診にて脾臟に $3 \mathrm{~cm}$ 大の腫瘤を指摘された。 単純 CT では低濃度、造影 CTでは腫瘍周囲に淡い造影効果を示 した。MRIではT $1 \cdot \mathrm{T} 2$ とも低信号で、拡張強調像では大部分 が低信号でへモジデリンの沈着が疑われた。腹部超音波検查では 中心部に血流を伴う低濃度腫瘤でペルフルブタンによる造影では 腫瘍辺縁部から中心に向かって造影効果を認めた。脾 sclerosing angiomatoid nodular transformation (SANT) を第一に考えるも、 画像診断では悪性腫瘍を完全には否定できず、患者も切除を強く 希望したため、腹腔鏡下脾臓摘出術を施行した。腫瘤は病理組織 学的にSANTと診断された。日常診療において脾腫瘍は比較的 まれな疾患である。その中でもSANTは2004年にMartelらによ り脾臓の血管腫類似病変として最初に報告された。医学中央雑誌 にて「sclerosing angiomatoid nodular transformation」をキー ワードに本邦報告例を検索すると、15件16例の報告を認めるのみ であった。今回われわれは稀な脾SANTの 1 例を経験したので、 本邦報告例の検討を併せて報告する。

62 巨大脾囊胞に対して腹腔鏡下囊胞天蓋切除術を施行し た 2 症例

札幌医科大学消化器 $\cdot$ 総合、乳腺 $\cdot$ 内分泌外科

及能大輔、水口徹、河野 剛、山口洋志、目黒 誠、今村将史、 木村康利、沖田憲司、信岡隆幸、竹政伊知朗

【はじめに】有症状の巨大脾囊胞に対して、腹腔鏡下囊胞天蓋切 除術（Laparoscopic dome resection：LDR）を2例に施行した ので報告する。【症例 1】29歳女性。左側腹部痛を認め前医に救 急搬送された。CTにて長径 $12 \mathrm{~cm}$ 大の単房性の脾囊胞を認め、脾 臓摘出術を锥められた。セカンドオピニオン目的に当院を受診し、 画像検査で悪性所見を認めず、LDRを施行した。手術は 3 port で行った。囊胞を穿刺して内溶液を吸引し、細胞診で悪性所見の 無い事を確認して囊胞壁を非実質境界部にて切離した。残存した 囊胞内膜を凝固し手術を終了した。術後合併症なく退院。【症例 2】 26歳男性。腹部超音波検查で左上腹部に $12 \mathrm{~cm}$ 大の腹部腫瘤を指 摘された。CTで脾上極の巨大脾囊胞と診断され、腹部の圧迫感 が以前より存在していたことから、加療目的に当科を受診。画像 検査で悪性所見を認めずLDRを施行した。手術は 3 portで行っ た。腹胿鏡下に囊胞壁を切開し内容液を吸引した後、同部位より dome resectionを行った。脾に残存した囊胞壁に対して可及的に 凝固を行い、止血を確認して手術を終了した。術後合併症なく退 院。摘出した 2 例の囊胞壁は、病理所見で悪性所見なく、上皮細 胞を認めず仮性脾囊胞と診断された。2 例とも無再発経過観察中 である。【まとめ】脾囊胞に対する治療法は従来脾摘術が多く行 われてきたが、近年LDR施行例の報告が増加しており、自験例 においても安全に施行しえた。今後はLDR施行症例の集積、長 期的な検討が必要であると考えられる。 
63 脾損傷後に発症した遅発性脾仮性動脈瘤の 3 例 市立札幌病院外科

大島由佳、上坂貴洋、齋藤健太郎、沢田克史、寺崎康展、皆川の ぞみ、奥田耕司、大島隆宏、大川由美、三澤一仁

近年、TAEを行える施設が多くなり、循環動態の安定した脾損 傷の急性期治療として非手術的治療が第一選択とされている。そ の一方で、遅発性脾仮性動脈瘤による脾破裂が重篤な合併症とし て挙げられる。今回、脾損傷に対し非手術的治療を行った後、逑 発性脾仮性動脈瘤を発症した 3 例を経験したので、文献的考察を 含めて報告する。

症例 1 は46歳男性。交通外傷のため救急搬送された。CTにて脾 損傷認め、TAE施行。6 病日目に退院となったが、受傷後13日 目に呼吸苦にて来院。貧血進行認めておりCT施行したところ、 脾破裂を認め再度 TAE施行した。症例 2 は33歳男性。スノーボ ード中に転倒し救急搬送され、CTで脾損傷認めた。CT上、活 動性の出血はなく保存的加療の方針とした。13病日にフォロー CT 施行したところ仮性動脈瘤認め、TAE施行した。症例 3 は調 教中の競走馬に蹴られて救急搬送。CTで脾損傷認めたため、 TAE施行となった。15病日目にフォローCT施行したところ仮性 動脈瘤認め、再度 TAE施行となった。

脾仮性動脈瘤が破裂すれば危機的状況に陥る可能性もあるため、 非手術的治療を行った脾損傷患者においては、遅発性脾破裂の発 生を念頭に慎重なフォローが必要である。 